\title{
A review on the tectonic evolution of the Paleozoic-Triassic basins from Patagonia: Record of protracted westward migration of the pre-Jurassic subduction zone
}

\author{
Rodrigo Suárez ${ }^{\mathrm{a}, *}$, Pablo D. González ${ }^{\mathrm{b}}$, Matías C. Ghiglione ${ }^{\mathrm{a}}$ \\ ${ }^{a}$ Instituto de Estudios Andinos (Universidad de Buenos Aires - CONICET), Buenos Aires, Argentina \\ ${ }^{\mathrm{b}}$ Instituto de Investigación en Paleobiología y Geología (Universidad Nacional de Río Negro - CONICET), General Roca, Argentina
}

\section{A R T I C L E I N F O}

\section{Keywords:}

Patagonia

Antarctic Peninsula

Accretionary orogenesis

Retreating slab

Pre-Jurassic

Paleozoic-Triassic basins

Detrital zircons

\begin{abstract}
A B S T R A C T
The Paleozoic-Triassic Patagonian basins, at present comprising the Andean hinterland and structural basement of active basins, document a pre-Jurassic evolution associated with accretionary processes at the paleo-Pacific convergent margin. The Early Cambrian basins constitute the earliest record for the emplacement of the Terra Australis Orogen in northern Patagonia and preserve metavolcanic strata derived from an extensional magmatic arc. Together, pre-Jurassic basins document the Early Cambrian to Late Triassic oceanward migration of the trench-forearc system, evidencing that slab retreat was the common subduction setup. Tectonostratigraphy of these basins can be divided into three major sequences, from east to west: (i) early-middle Cambrian, (ii) Silurian-Carboniferous and (iii) Late Permian-late Triassic, which are separated by angular unconformities, evidencing large deformational pulses (advancing stages?) at Early Ordovician, early-middle Permian, and Late Triassic-Early Jurassic times. The Early Cambrian basins are mainly represented in the North Patagonian Massif by the Nahuel Niyeu forearc basin and the El Jagüelito backarc basin, which were closed and metamorphosed during the Early Ordovician. The Silurian-Devonian clastic sequences of the Atlantic region and Malvinas Islands evolved in an intracontinental rift setting and were deformed in the Permian when thrust tectonics took place at the continental scale, while the contemporaneous trench-forearc system represented in western Patagonia was governed by slab dynamics and accretion of oceanic material. During the final Pangea assembly (PermianTriassic), the Antarctic Peninsula crustal block formed part of Patagonia as evidenced the detrital zircons record in the Permian-Triassic arc-flank basins. Deformation and metamorphism of these late Paleozoic-early Mesozoic basins could have occurred during the latest Triassic-Early Jurassic Chonide event.
\end{abstract}

\section{Introduction}

After the appearance of mobilistic theories about continental drift related to the concept of plate tectonics in the '60s, numerous ideas emerged that involved terrane accretions. Patagonia did not escape to this conception and has been the locus of several discussions about its origin. Ramos (1984) formalized the theory of the allochthonous origin of the Patagonia terrane with respect to the West Gondwana margin represented by the Río de la Plata Craton and the Sierras Pampeanas mobile belt (Fig. 1). Although the allochthonous origin of Patagonia still remains under discussion, this proposal was a starting point to subsequent research and gave way to diverse theories that booted the investigation and geological knowledge about the Patagonian basement (Forsythe, 1982; Rapalini, 1998; Pankhurst et al., 2003, 2006, 2014;
Gregori et al., 2008; Rapalini et al., 2010, 2013; González et al., 2011b, 2018; Tomezzoli, 2012; Chernicoff et al., 2013; Ramos and Naipauer, 2014; Hervé et al., 2016; Calderón et al., 2016; Castillo et al., 2016, 2017; Greco et al., 2017; among others).

Paleozoic-early Mesozoic paleogeographic reconstructions of Gondwana, based on quantitative paleomagnetic data, still have large error ranges regarding the relative position of Patagonia and the Antarctic Peninsula. This uncertainty lies in the scarce paleopoles obtained in Patagonia (Rapalini et al., 1994; Rapalini, 1998; Luppo et al., 2019), while in the Antarctic Peninsula, the Cretaceous Palmer Land Event (Vaughan and Storey, 2000; Vaughan et al., 2012) produced an important remagnetization in Paleozoic-Jurassic rocks (Grunow, 1993; Poblete et al., 2011), which makes infeasible to determinate a preCretaceous apparent polar wandering path (e.g. Poblete et al., 2011).

\footnotetext{
* Corresponding author. Instituto de Estudios Andinos IDEAN (Universidad de Buenos Aires - CONICET), Intendente Güiraldes 2160, Ciudad Universitaria Pabellón II C1428EGA - CABA, Argentina.

E-mail addresses: rsuarez@gl.fcen.uba.ar, rodrigo_s_37@hotmail.com (R. Suárez).
} 


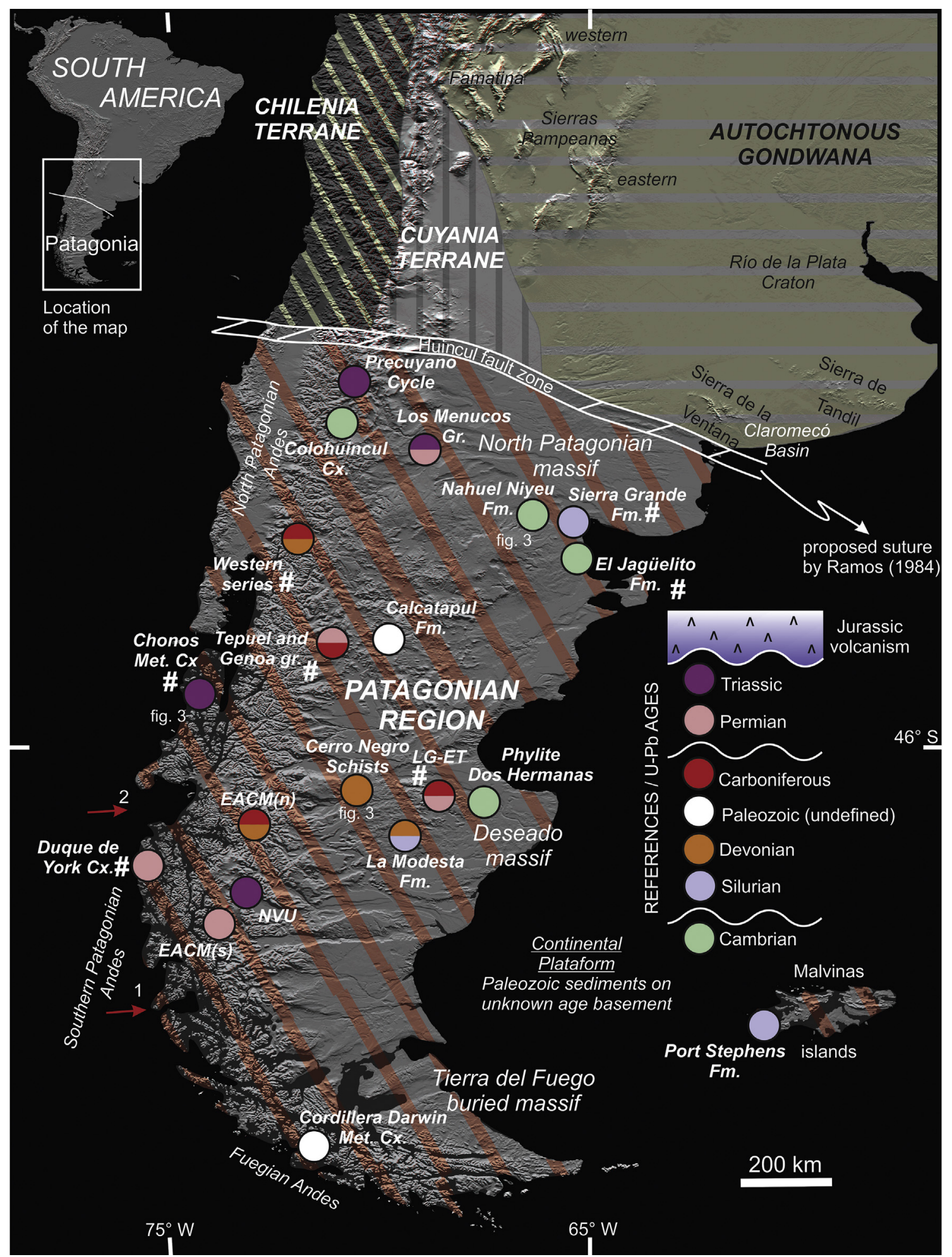

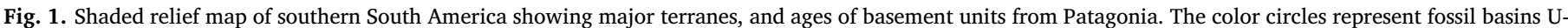

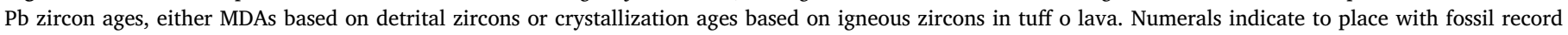

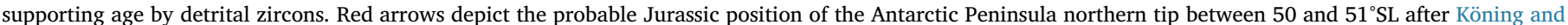

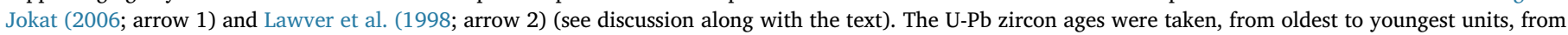

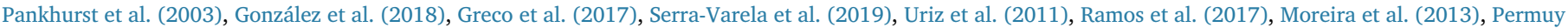

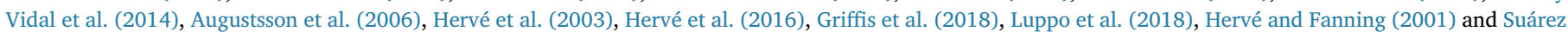

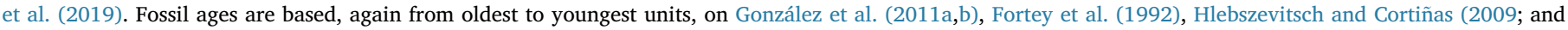

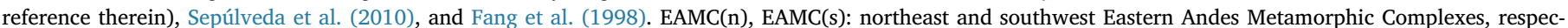

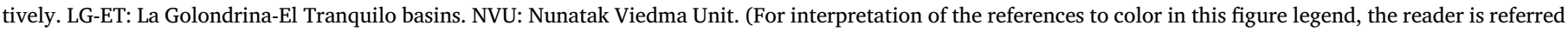
to the Web version of this article.) 
Added to this, there is no single accepted model of geometrical fit previous to the Middle Jurassic between Patagonia and Antarctic Peninsula derived from geophysical data (see discussion in Ghidella et al., 2007).

The Terra Australis Orogen (see Cawood, 2005) implanted along the paleo-Pacific - Iapetus margin of Gondwana, from the Neoproterozoic to the early Mesozoic, preserves the record of a long-lived history of oceanic subduction beneath the convergent margin. We use this pattern as a template, to appraise numerous recent $\mathrm{U}-\mathrm{Pb}$ zircon ages on the metasedimentary and plutonic units together with new tectonic interpretations about basin nature (Uriz et al., 2011; Riley et al., 2012; Moreira et al., 2013; Permuy Vidal et al., 2014; Castillo et al., 2016, 2017; Hervé et al., 2016; Greco et al., 2017; Ramos et al., 2017; González et al., 2018; Serra-Varela et al., 2019; Suárez et al., 2019). Thus, the purpose of this review is to summarize the evolution of preJurassic basins and propose a geodynamical framework based on the accretionary orogenesis of the western Gondwana margin.

\section{Overview of Patagonia in Gondwanaland}

The different Paleozoic basement blocks that conform Patagonia have been considered either allochthonous (Ramos, 1984, 2008; Ramos and Naipauer, 2014), parautochthonous (Pankhurst et al., 2006; Rapalini et al., 2010; González et al., 2018), or even autochtonous to South America (Forsythe, 1982; Gregori et al., 2008; Rapalini et al., 2013; Greco et al., 2017). Strong Gondwana affinities are present in the involved pre-Jurassic sequences, as revealed by their stratigraphy, fossil record, and detrital zircons patterns (Pankhurst et al., 2003, 2014; Naipauer et al., 2011; González et al., 2011a, 2011b, 2018; Ramos and Naipauer, 2014; Castillo et al., 2016; Greco et al., 2017; among others). Therefore, it is considered that the origin and evolution of Patagonia involved proximity to the Gondwana edge.

Thus, as a starting point, the Patagonian basement terranes evolved in the context of the Terra Australis Orogen in Gondwana (Fig. 2) from
Neoproterozoic to early Mesozoic times (see review in Cawood, 2005). The nature and evolution of this long-lived accretionary orogen provide a template to understand the pre-Jurassic evolution of Patagonia and its connection with the Antarctic Peninsula.

\subsection{From Rodinia to the Pangea assembly, and the opening of the Panthalassa ocean}

The pieces that were part of Patagonia during the final assembly of Pangea (Permian-Triassic boundary by Gallo et al., 2017) had an evolution delineated by several orogenic phases, inherent to the evolution of the Terra Australis Orogen (Fig. 2; Pankhurst et al., 2003, 2014; Cawood, 2005; Varela et al., 2009; Castillo et al., 2017; Greco et al., 2017; González et al., 2018). Particular cases are the Malvinas Islands and surrounding submerged areas from the Argentinean continental shelf, whose Proterozoic basement is currently considered as a single continental block together with Patagonia (Platt and Philip, 1995; Ramos et al., 2017; Schilling et al., 2017; Chemale et al., 2018). This Atlantic region, which is now mainly below the sea level, yielded the oldest in situ basement ages, ranging from Mesoproterozoic to Neoproterozoic (Cingolani and Varela, 1976; Jacobs et al., 1999; Chemale et al., 2018), that may reflect an early evolution related to the Rodinia Supercontinent (Wareham et al., 1998; Ramos, 2010; Schilling et al., 2017).

The amalgamation of Rodinia occurred at around of 1200-1000 Ma (Pisarevsky et al., 2003) producing a characteristic phase of orogenic activity known as the Grenvillian orogeny. Since detrital zircons yielding ages between 1200 and $1000 \mathrm{Ma}$ are abundant in the record of the fossil basins from Patagonia (see review in Ramos, 2010), they are a controversial matter regarding possible Greenvillian source areas. The breakup of the Rodinia supercontinent at ca. 800-700 Ma, gave way to Laurentia and Gondwana (Pisarevsky et al., 2003), and the opening of the Iapetus and Panthalassa (i.e. paleo-Pacific) oceans (Cawood et al., 2001; Cawood, 2005). These oceans underwent different evolutionary

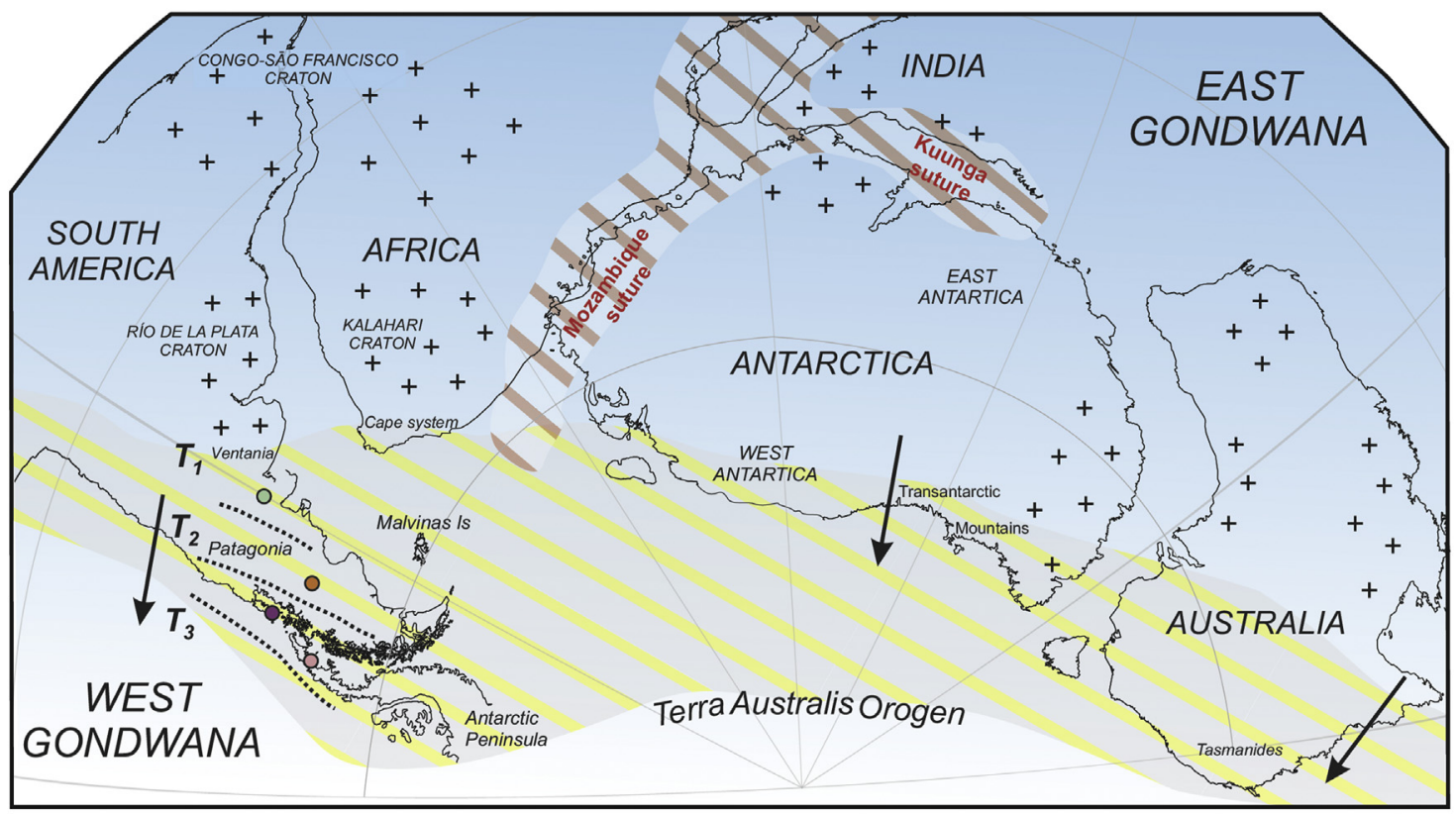

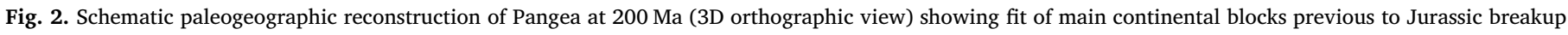

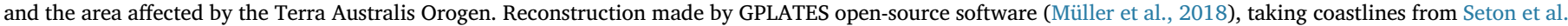

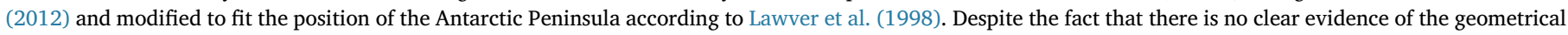

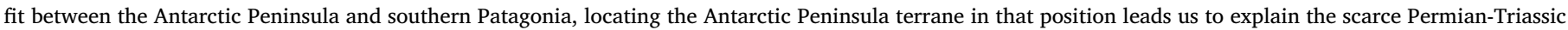

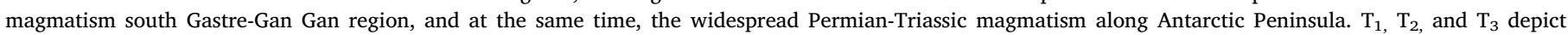

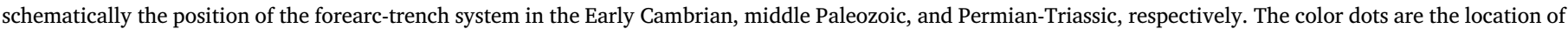

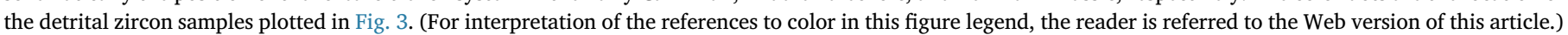


histories: while the Iapetus Ocean was mainly consumed beneath Laurentia producing the mid-Paleozoic Caledonian collisional orogeny (van Staal et al., 1998; Domeier, 2016), the paleo-Pacific ocean still remains open (Cawood, 2005). As we will explain, Patagonia records a protracted east-dipping oceanic subduction along the paleo-Pacific margin since Neoproterozoic (?)-Early Cambrian times.

The amalgamation of Gondwana occurred during the Neoproterozoic-Cambrian, as a consequence of the accretion and collision of several terranes (Cawood and Buchan, 2007; Oriolo et al., 2017; Schmitt et al., 2018). The collision of the Kalahari Craton against the Congo Craton at $\sim 530-520 \mathrm{Ma}$ is considered the latest collisional event (Oriolo et al., 2017). At this stage, the final Gondwana assembly involved several blocks: Australian-Antarctic and Indo-Antarctic cratons forming East Gondwana, and several cratons as Río de la Plata, Congo-São Francisco, and Kalahari cratons, among others, in West Gondwana (Fig. 2; Boger and Miller, 2004; Oriolo et al., 2017). The sutures between these cratons remain from plate collisions and ocean closures driven by the Brasiliano - Pan-African orogeny (Fig. 2; Boger and Miller, 2004).

Subduction started along East Gondwana (Antarctica-Australia) in the Neoproterozoic, concomitant with the final Rodinia breakup (Oriolo et al., 2017), and was followed by subduction along the West Gondwana margin during the Ediacarian-earliest Cambrian (c. 560$540 \mathrm{Ma}$; Cawood and Buchan, 2007). The onset of subduction is considered as the beginning of the Terra Australis accretionary orogen (Cawood, 2005; Cawood and Buchan, 2007), which extends along the remains of the Iapetus - paleo-Pacific margin of Gondwana between Australia-New Zealand and into South America (Cawood, 2005).

Inherent to the evolution of the Terra Australis Orogen, a series of orogenic events occurred in the western Gondwana margin. In Patagonia, several orogenic phases have been differentiated: the Neoproterozoic-Cambrian Pampean/Ross orogeny (Rapalini et al., 2013, Chernicoff et al., 2013; Ramos and Naipauer, 2014; Pankhurst et al., 2014; Greco et al., 2017; González et al., 2018), Ordovician-Devonian Famatinian orogeny (Varela et al., 2005, 2009; Pankhurst et al., 2014), Carboniferous-Permian Gondwanide orogeny (von Gosen, 2003; Pankhurst et al., 2006; Ramos, 2008; Varela et al., 2009; Giacosa et al., 2012; González et al., 2016; Oriolo et al., 2019) and the recently defined Late Permian-Triassic Tabarin orogeny (Heredia et al., 2018) followed by the latest Triassic-Early Jurassic deformational Chonide event (Hervé et al., 2008; Navarrete et al., 2019). Through all these Paleozoic-early Mesozoic orogenic phases, the trench-forearc system exhibits a pattern of migration towards the current Pacific margin (Figs. 2 and 3).

The Gondwanide orogeny in Patagonia, early recognized by the pioneer works of Keidel (1916) and Du Toit (1927), affected the entire Terra Australis Orogen (Cawood and Buchan, 2007). Some authors postulate that the Gondwanide orogeny culminated with terrane collision, such as the collision of Patagonia against the southernmost margin of South America in the Late Paleozoic for instance (von Gosen, 2003; Ramos, 2008). Analysis of new paleomagnetic poles from the North Patagonian Massif suggests that, if a collision occurred, the final stage took place at around of the Permian-Triassic boundary (Luppo et al., 2019). The Patagonia collision model adequately explains the opposite vergence of the Gondwanide deformation on both sides of the Huincul fault zone (Fig. 1), although necessary evidence of ocean closure are still missing in northern Patagonia to validate this model (e.g. see Gregori et al., 2008, Pankhurst et al., 2014, and Castillo et al., 2017). Alternatively, it was also proposed the collision of the Deseado terrane against the southern margin of northern Patagonia (Ramos, 2004; Pankhurst et al. 2006; Schilling et al., 2017). In contrast, other authors explain this contractional-transpressional deformation phase by noncollisional processes (Trouw and De Wit, 1999; Gregori et al., 2008; Dalziel et al., 2013).

At the beginning of the Triassic, prior to the Early Jurassic continental breakup (Jokat et al., 2003; König and Jokat, 2006; Ghidella et al., 2007), Patagonia and the Antarctic Peninsula, are interpreted to have formed a single continental block. Following the opening of the Weddell sea (Ghidella et al., 2007) and the Drake Passage, several pieces were dispersed in the southern oceans, setting the present-day tectonic plate framework (Poblete et al., 2016).

\section{Age and distribution of the fossil basins}

Our review is focused on two main regions, where metasedimentary units are well-exposed (Fig. 1): (i) the eastern North Patagonian Massif, represented by low-grade metagreywackes and phyllites, interbedded with metavolcanic rocks of lower Cambrian age, which are unconformably covered by Silurian-Devonian quartzites; (ii) Silurian to Triassic metasedimentary rocks extending from the western Deseado Massif to the Chilean coast.

\subsection{Neoproterozoic-lower Paleozoic units}

Neoproterozoic-Early Cambrian maximum depositional ages from detrital zircons in metasedimentary units are only available from the Dos Hermanos phyllites cropping out in the Deseado Massif (Martínez, 2002; Pankhurst et al., 2003). On the other hand, Cambrian metasedimentary units are distributed mainly in the eastern and northern flanks of the North Patagonian Massif (Fig. 1). In the northern region, the Nahuel Niyeu Formation (520-510 Ma) is composed mainly of metagreywackes and phyllites with minor intercalations of tholeiitic meta-igneous bodies (Greco et al., 2015, 2017). Close to the Atlantic coast (Fig. 1), the El Jagüelito Formation (535-515 Ma) contrasts with the Nahuel Niyeu Formation due to the presence of a larger proportion of acidic metavolcanic rocks (Fig. 4) with high-K calc-alkaline geochemical signature (González et al., 2018). As indicated by provenance studies, geochemical indicators and stratigraphical correlations, the Nahuel Niyeu Formation occupied a forearc position (Greco et al., 2017) while El Jagüelito Formation exhibits features akin to a backarc basin (González et al., 2018). This tectonic setting is further supported by plutonic rocks of early Cambrian age with calk-alkaline geochemistry and trace elements typical from subduction-related melts (i.e. Tardugno Granodiorite unit; Chernicoff et al., 2013; Rapalini et al., 2013; Pankhurst et al., 2014). In contrast, the protoliths of the El Jagüelito Formation have been interpreted as deposits of a molasse basin associated with collisional orogenesis (Ramos and Naipauer, 2014) during the Ross orogeny in Antarctica (Ramos and Naipauer, 2014). On the other hand, in the San Martín de Los Andes area, detrital zircon data from Andean basement rocks yielded late Cambrian maximum depositional ages for the protolith of the high-grade Colohuincul Formation (Serra-Varela et al., 2019). Likewise, an anatectic granite dated at $434 \mathrm{Ma}$ intruded into already deformed and metamorphosed basement rocks, and thus the Cambrian age of this basement is doubtful, being extended up to the Ordovician-Silurian (Serra-Varela et al., 2019).

The Ordovician seems to be an important period of deformation and uplift, with scarce or non deposition, since the Silurian-Devonian sequences overlie unconformably the folded basement and granites in the North Patagonian Massif (Fig. 4) and Malvinas Islands, respectively (Du Toit, 1927; Spalletti, 1993; Hunter and Lomas, 2003; González et al., 2008; Ramos et al., 2017).

\subsection{Silurian-Devonian units}

Sedimentary and metasedimentary rocks of late Silurian-Devonian age are distributed in two main regions: along the Atlantic coast region, lying in angular unconformity over the pre-Silurian basement (Fig. 1; Martínez, 2002; Ramos et al., 2017) and in the western Deseado Massif (Moreira et al., 2005, 2013).

The Sierra Grande Formation and the Cabo Blanco beds, mainly consisting of successions of quartz-rich sandstones (Spalletti, 1993; Márquez and Navarrete, 2011), crop out in the eastern North 


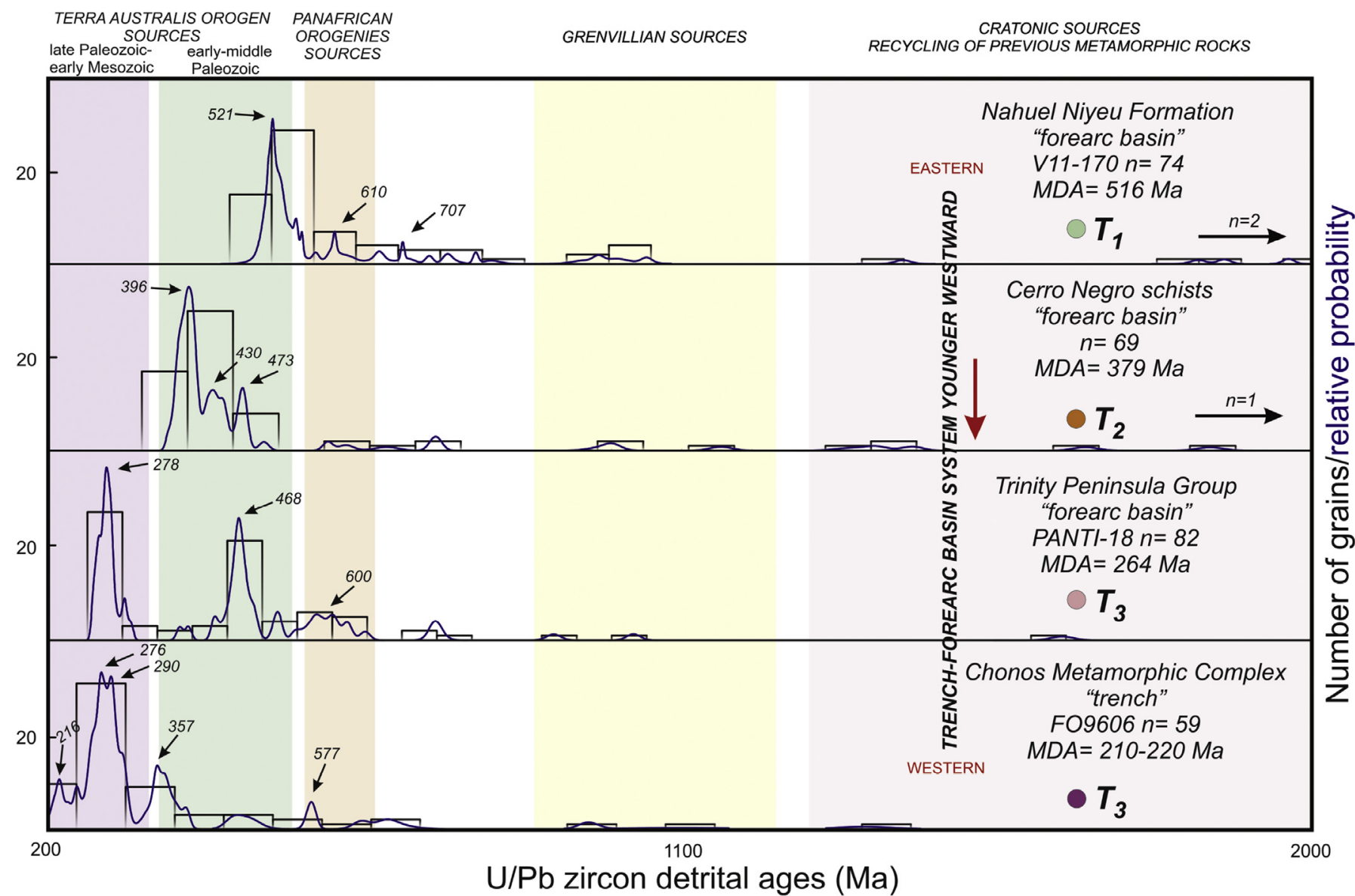

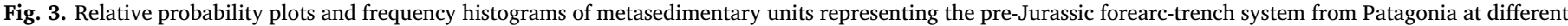

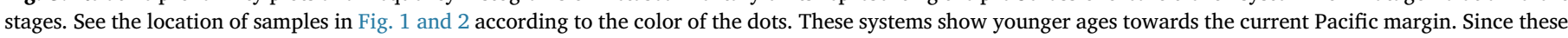

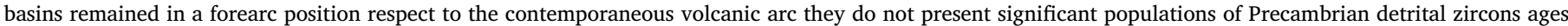

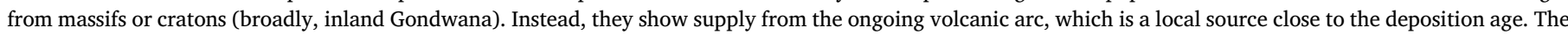

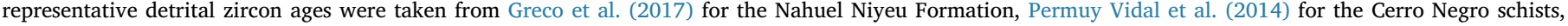

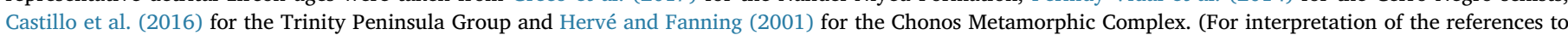
color in this figure legend, the reader is referred to the Web version of this article.)

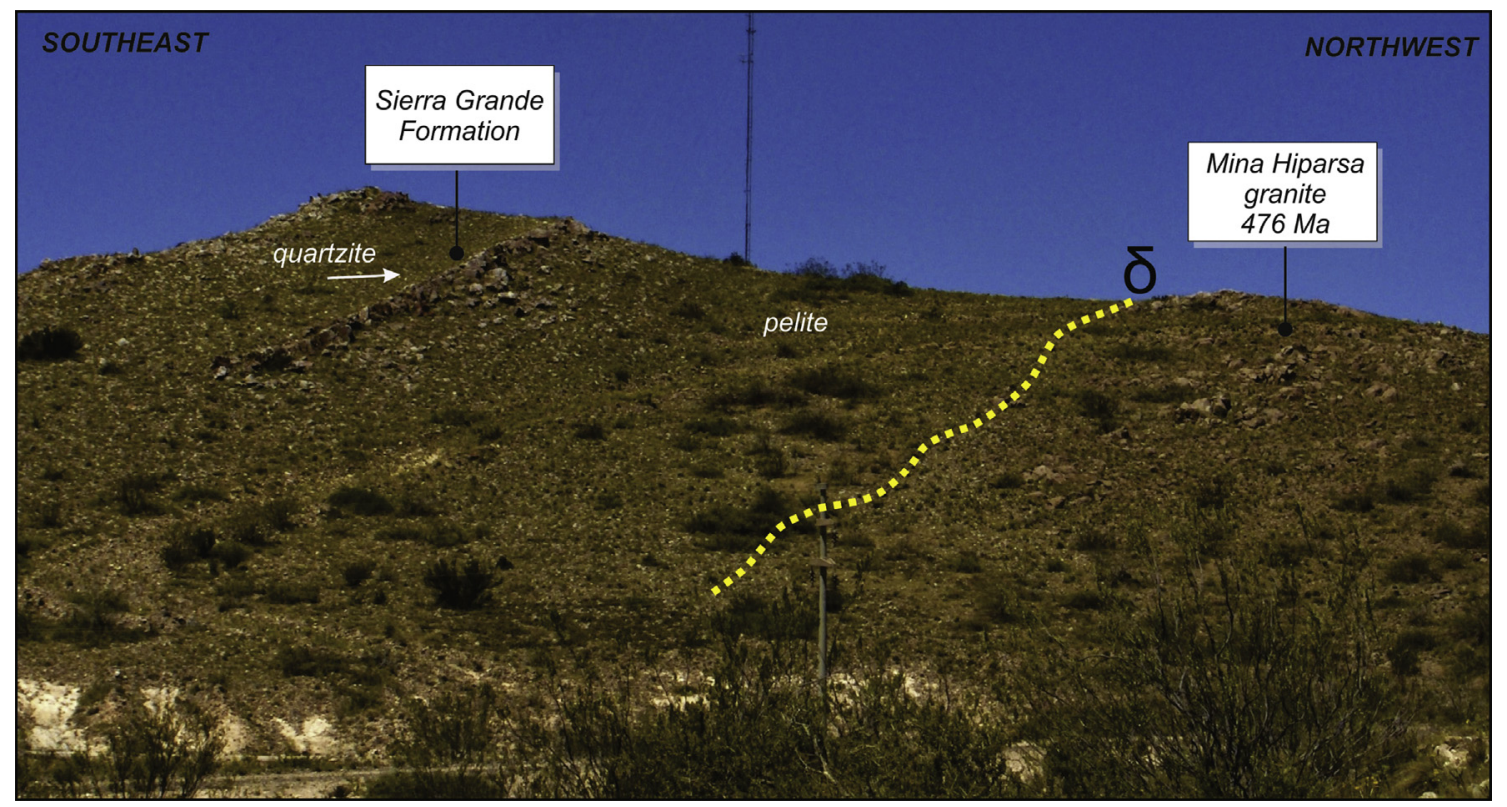

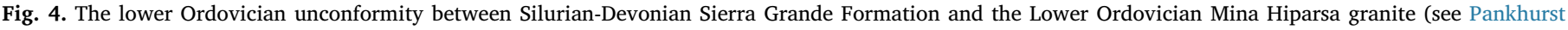
et al., 2006 and Varela et al., 2009), evidencing a deformation and uplift pulse in Ordovician times. 
Patagonian and Deseado massifs, respectively (Spalletti, 1993; Márquez and Navarrete, 2011; Uriz et al., 2011). The lower member of the Sierra Grande Formation (Polker Member) exhibits a detrital zircon age distribution with a younger peak at $\sim 501 \mathrm{Ma}$ (Pankhurst et al., 2006; Naipauer et al. 2011); and broadly this unit exhibits faunas characteristic of the Hirnantian-early Silurian boundary (Rustan et al., 2013; Siccardi et al., 2014; see also Müller, 1965; Manceñido and Damborenea, 1984), reaching the Devonian age (Spalletti, 1993 and references therein).

Silurian-Devonian units from eastern Patagonia are possibly correlative with the Port Stephens and Fox Bay formations in the Malvinas Islands (Ramos et al., 2017). The sedimentological analysis suggests a siliciclastic platform shared with southern Africa as the depositional environment (Spalletti, 1993), while another geodynamical model proposed the deposition of the Sierra Grande Formation in a passive margin correlatable with the lower Beacon Supergroup of Antarctica (Ramos and Naipauer, 2014). Considering the current geographical position of the Malvinas Islands (autochtonous and non-rotational model by Platt and Philip, 1995; Ramos et al., 2017; Schilling et al., 2017), paleocurrents and facies analyses suggest E-to-NE basin deepening (Hunter and Lomas, 2003).

The La Modesta Formation from western Deseado Massif is composed of a broad variety of lithologies such as schists, metavolcanic rocks, and calcsilicates interbedded with metaturmalinite beds (Moreira et al., 2005, 2012), yielding late Silurian (?)-Early Devonian maximum depositional ages (Moreira et al., 2013). In the North Patagonian Massif, Devonian ages for maximum sedimentation of the Calcatapul Formation are under discussion (von Gosen and Loske, 2004). This unit is mainly composed of a sequence of metapyroclastic rocks, interpreted as intra-arc to back-arc basin magmatic products, and could be of Devonian-Carboniferous age since it is intruded by Permian granites (von Gosen and Loske, 2004). Besides, high-grade schists of the Cushamen Formation (Giacosa et al., 2004) exhibit Devonian youngest detrital zircons (Hervé et al., 2005).

\subsection{Late Devonian-early Carboniferous units}

Low-grade metasedimentary rocks of quartz-rich turbiditic protoliths are widely distributed in southern Patagonia (Forsythe, 1982; Hervé et al., 2003, 2008; Augustsson et al., 2006; Giacosa et al., 2012) constituting the backbone of the Southern Patagonian Andes (Giacosa and Márquez, 2002; Ghiglione et al. 2018). The main stratigraphic unit is the Eastern Andes Metamorphic Complex (EAMC in Fig. 1, Hervé et al., 2008), including the Río Lacteo and Bahía de la Lancha formations (Calderón et al., 2016) exposed in the eastern foothills of the Patagonian fold and thrust belt (Riccardi, 1971; Kraemer and Riccardi, 1997; Bell and Suárez, 2000; Giacosa and Márquez, 2002; Giacosa et al., 2012). The EAMC yields a MDA spanning 390-320 Ma (Late Devonian-early Carboniferous; Augustsson et al., 2006) for its northern sector (EAMCn), and Permian-Triassic for its southern segment (EAMCs). The development of the EAMC was in part synchronous with the Cerro Negro Schists from the western Deseado Massif (Permuy Vidal et al., 2014).

The depositional geodynamic environment of the EAMCn protoliths is still under discussion, and is interpreted principally in two different ways: (i) as a passive margin sourced from the cratonic interior, based on geochemical and provenance data (Hervé et al., 1999; Augustsson and Bahlburg, 2003a; 2003b, 2008; Lacassie, 2003), or (ii) as sequences formed along the active paleo-Pacific margin (Forsythe, 1982; Giacosa and Márquez, 2002; Moreira et al., 2005; Ramos, 2008; Permuy Vidal et al., 2014). The latter option is supported by provenance studies based on $\mathrm{U}-\mathrm{Pb}$ zircon ages, geochemistry of whole rock, major and trace elements of Cerro Negro schist data, indicating sources from an active magmatic arc (Permuy Vidal et al., 2014). Furthermore, Late Devonian MDA ages for the schist (Permuy Vidal et al., 2014) suggest that they were concomitant with plutonic ages from a NW-SE magmatic belt from the Northern Patagonian Andes to the Deseado Massif (Varela et al., 2005, 2009; Pankhurst et al., 2006; Ramos, 2008; Hervé et al., 2016), interpreted as representative of a subduction-related Devonian-Carboniferous magmatic arc (Fig. 6; Varela et al., 2005, 2009; Ramos, 2008).

\subsection{Late Paleozoic Gondwanide units}

Marine environments with glacial influence characterize the late Paleozoic from Patagonia (Riccardi, 1971; González Bonorino, 1992; Poiré et al., 1999; Limarino and Spalletti, 2006; Marcos et al., 2018). According to Limarino and Spalletti (2006), the Gondwanide basins could be discriminated into intraplate, retroarc or arc-related basins. While the Permian La Golondrina basin in the Deseado Massif presents an extensional intraplate character (Giacosa et al., 2010), other basins represented by the Bahía de la Lancha Formation and the Tepuel-Genoa groups are classified as retroarc basins (González Bonorino, 1991, 1992, Limarino and Spalletti, 2006). Alternatively, a forearc position for the Tepuel-Genoa Basin has been suggested based on the relatively close position of the Devonian-Carboniferous magmatic arc (Fig. 6; Ramos, 2008; Marcos et al., 2018). Provenance sources, based on sandstone modal analysis from Tepuel Group (Late Carboniferous-Permian) of the Tepuel-Genoa Basin, exhibit supply from recycled orogen (Ciccioli et al., 2018).

Late Paleozoic metadiamictite rocks of glacimarine protoliths were described in the western North Patagonian Massif (Hervé et al., 2005; Marcos et al., 2018), as intercalations of the Cushamen Formation, which is mainly composed of medium-grade schists (Giacosa et al., 2004). According to Marcos et al. (2018), the Tepuel-Genoa and Cushamen basins were concomitants, although somehow not completely disconnected by the Silurian-Devonian and Carboniferous magmatic arc rocks. Carboniferous sedimentation from the Bahía de la Lancha Formation (Augustsson et al., 2006), in a coastal marine environment with glacial influence (Poiré et al., 1999; 2003), could be an equivalent to the north Patagonian units.

\subsection{Late Permian-Triassic units}

The upper Permian-Triassic volcanogenic rocks from the North Patagonian Massif, such as the Los Menúcos Complex (Llambías and Rapela, 1984; Rapela and Llambías, 1985; Cucchi et al., 2001; Falco and Hauser, 2017; Luppo et al., 2018) and Treneta and Puesto Piris formations (Rapela and Caminos, 1987; Caminos, 2001) and correlative volcanic units (González et al., 2016, 2017) rest unconformably onto the continental basement deformed by the early-middle Permian Gondwanide orogeny (González et al., 2017). Emplacement of these units would take place in an extensional context with an NE-SO main stretching direction (Giacosa et al., 2007; González et al., 2016). Farther west, in the southern region of the Neuquina Basin, Upper Triassic intermediate to acidic volcanic and pyroclastic rocks were deposited in an extensional retroarc basin (D'Elia et al., 2012).

In the southern Chilean Andes, the EAMCs (Augustsson et al., 2006), and the Duque de York Complex in the Madre de Dios Archipelago (Forsythe and Mpodozis, 1979, Fig. 1) are plausible equivalent units of the Trinity Peninsula Group in Antarctic Peninsula (Barbeau et al., 2009; Castillo et al., 2015, 2016). These Permian-Triassic metasedimentary rocks have been interpreted as remnants of the trench-forearc system (Hyden and Tanner, 1981; Hervé et al., 2006; Bradshaw et al., 2012; Castillo et al., 2015, 2016). Along the Chilean coast, the Chonos Metamorphic Complex (Fig. 1) represents the younger, accretionary prism of the Late Triassic-Early Jurassic subduction zone (Hervé et al., 1981; Fang et al., 1998; Willner et al., 2000; Hervé and Fanning, 2001).

Deposition of the Nunatak Viedma Unit on the Southern Patagonian Icefield (Fig. 1) has been recently constrained to the Late Triassic based on a $\sim 220$ Ma MDA and regional stratigraphic relationships (Fig. 5, Suárez et al., 2019). A cluster of Triassic detrital zircons ages are interpreted to be sourced from the Permo-Triassic active volcanic arc 


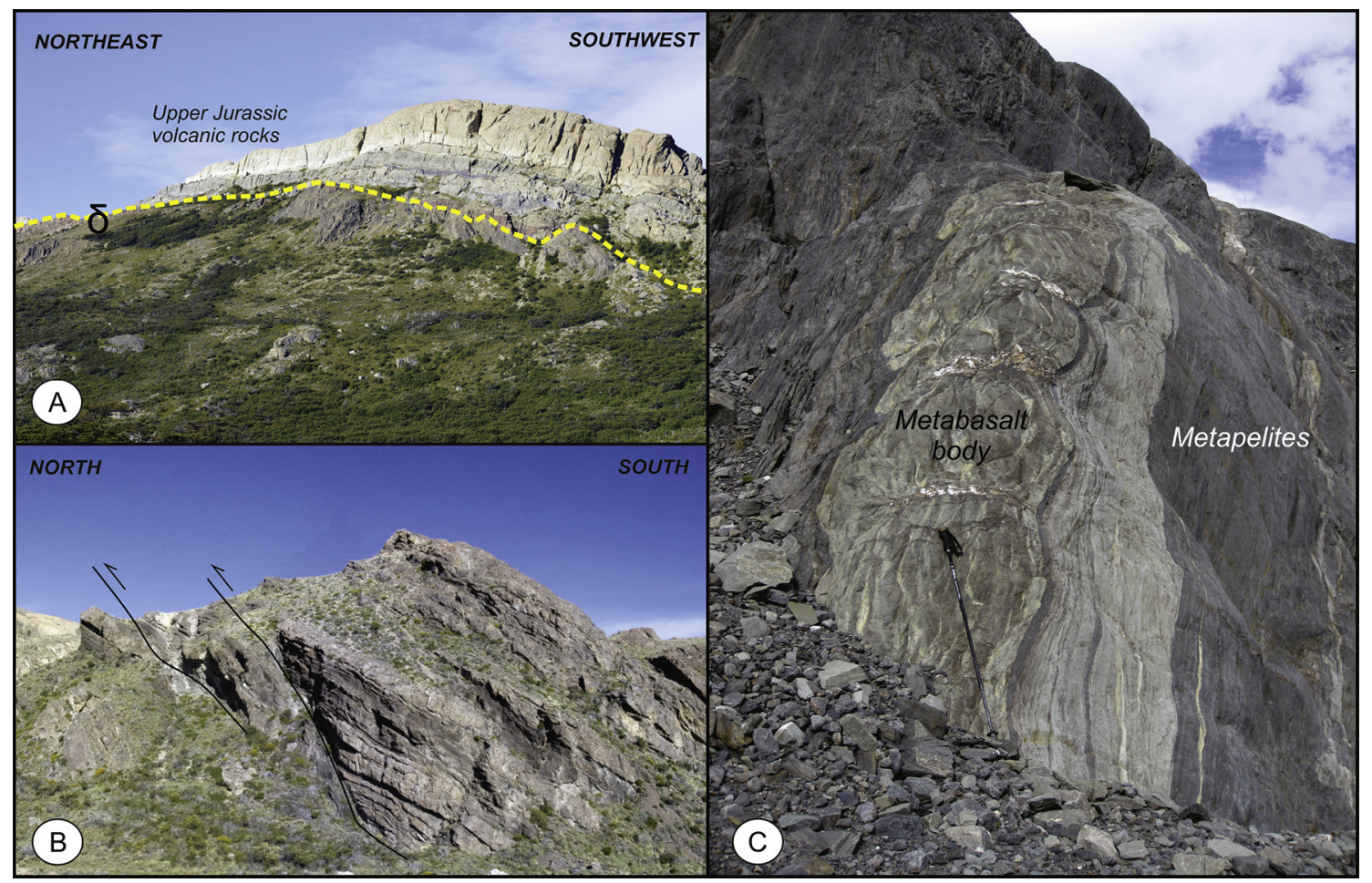

Fig. 5. Outcrops of the pre-Jurassic fossil basins from southern Patagonia. (a) The angular unconformity between metaturbidites of the Bahía de la Lancha Formation (Carboniferous) and Upper Jurassic volcanic rocks, evidencing exhumation, deformation and metamorphism occurred prior to the Late Jurassic (Cerro Polo, near El Chaltén). (b) Gondwanide thrusts (see Giacosa et al., 2012) affecting the Bahía de la Lancha Formation (type-locality). (c) Metabasaltic rocks interbedded in the metaclastic sequence from Upper Triassic in the Nunatak Viedma Unit (Viedma glacial, South Patagonian Icefield), deformed and metamorphosed during the latest Triassic-Early Jurassic.

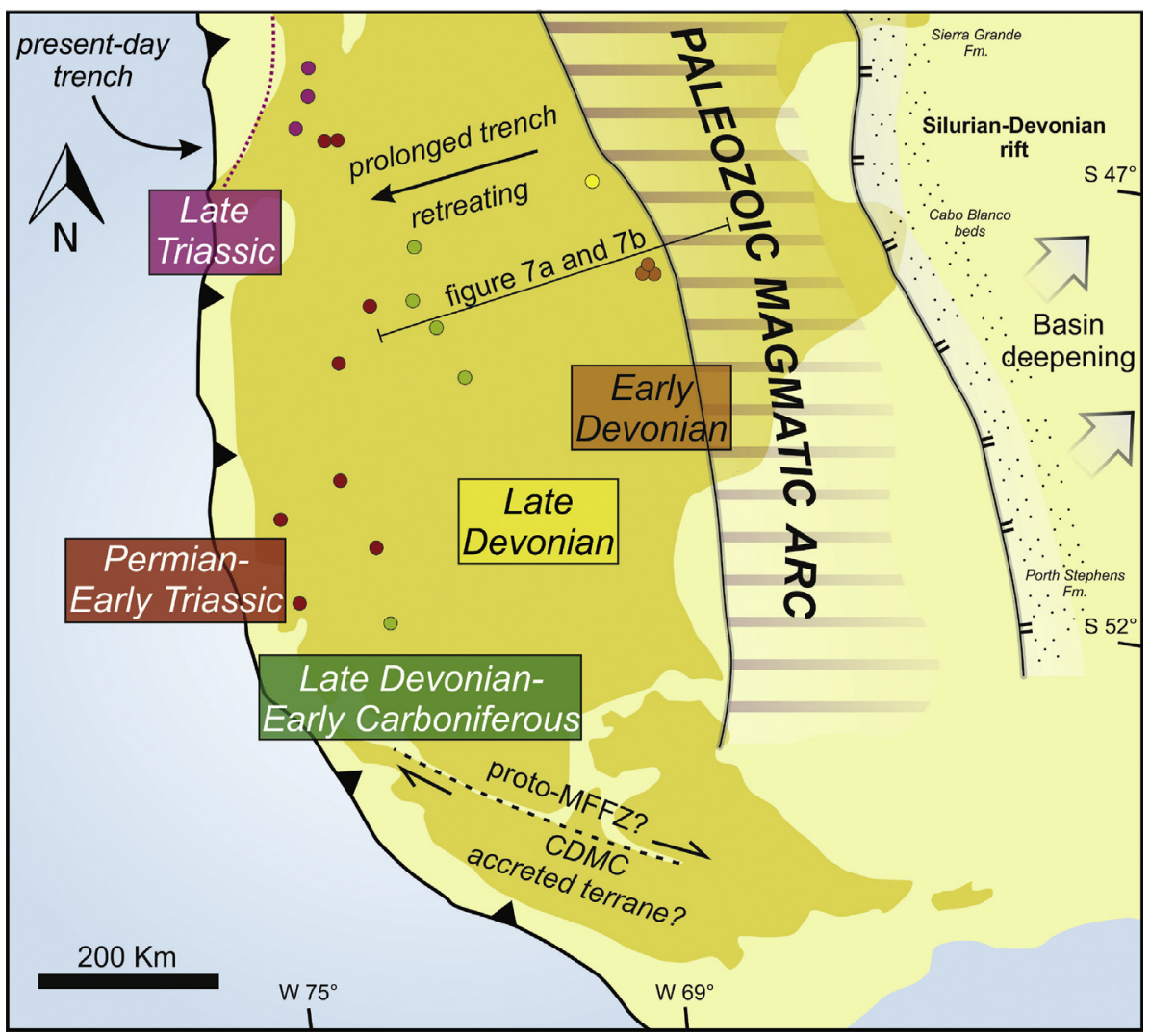

Fig. 6. The Paleozoic-early Mesozoic orogenic system in southern Patagonia. Color dots correspond to MDAs estimates from detrital zircon ages, which are younger westward. In the retroarc position, the rift basin is shared with inland Gondwana. Zircon detrital ages were taken from Hervé et al. (2003), Augustsson et al. (2006), Moreira et al. (2013) and Permuy Vidal et al. (2014). Interpretation of CDMC and protoMFFZ are based on Hervé et al., (2010b). CDMC: Cordillera Darwin Metamorphic Complex. MFFZ: Magallanes-Fagnano fault zone. (For interpretation of the references to color in this figure legend, the reader is referred to the Web version of this article.) 


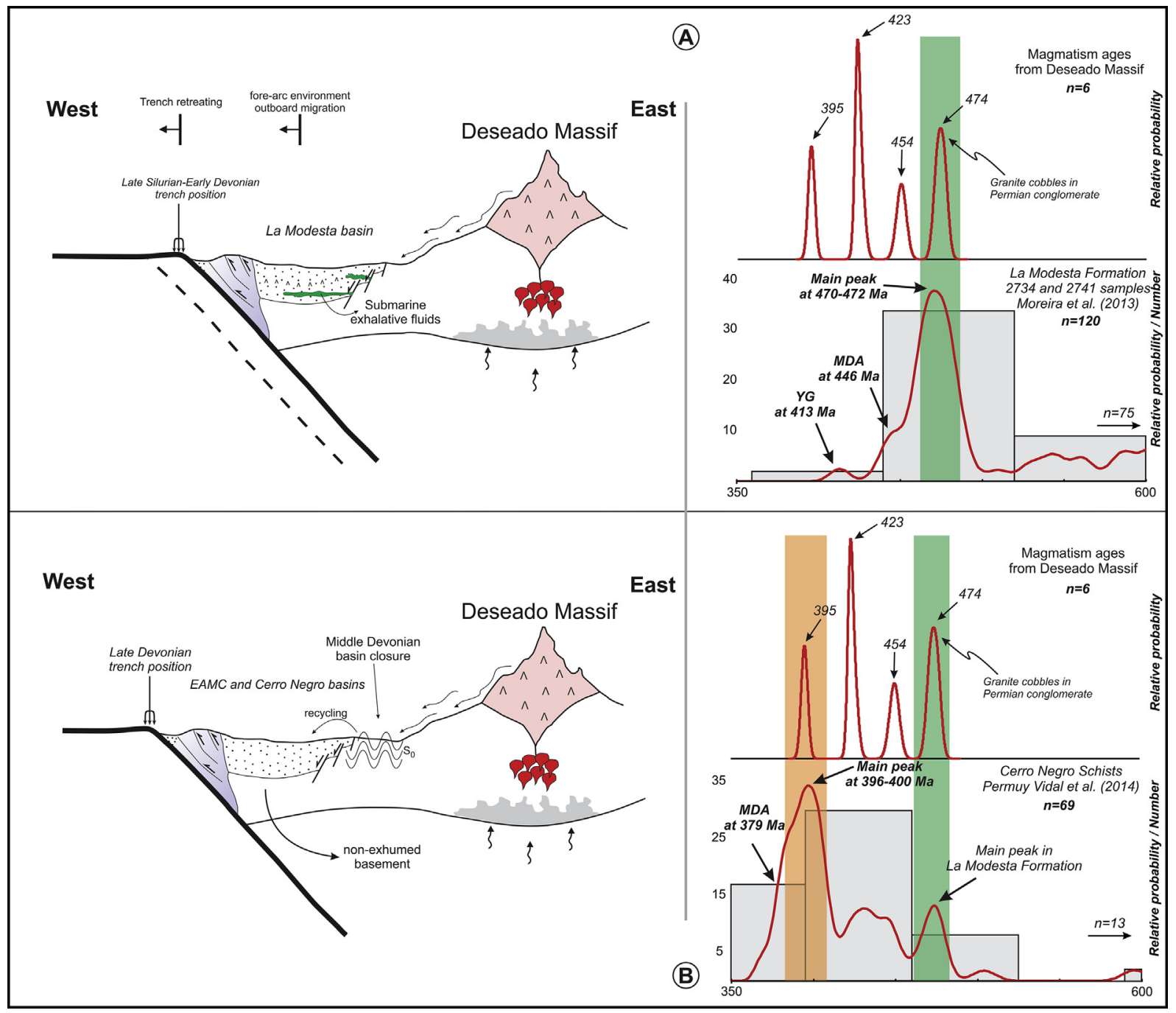

Fig. 7. Interpretation on Silurian-Devonian orogen dynamics from southern Patagonia and their implications on the continental crust growth trough sediment accretion, subduction-related magmatism and basin closure. (A) and (B) represent the trench-forearc system at different stages while no deformation occurred in the retroarc-cratonic region. Right inset in each panel shows the detrital zircon age distribution from the forearc basin and its correlation with source area.

emplaced along the Antarctic Peninsula, suggesting a retroarc position for the basin (Suárez et al., 2019). It contrasts with the classic vision of that the entire belt the Late Paleozoic-Early Mesozoic metamorphic complexes of the Patagonia Andes were part of an accretionary prism (e.g. Forsythe, 1982). Additionally, petrographic provenance studies on sandstones and geochemical data from volcanic rocks of the Triassic El Tranquilo Group fall in the field of magmatic arc, showing input from acidic igneous sources (Jenchen, 2018).

\section{Geodynamic setting}

To elucidate the puzzling basin evolution associated with the Terra Australis orogen in Patagonia-Antarctic Peninsula, we examined some pre-Jurassic key basins evaluating lithologic, tectonostratigraphy, structural, and geochronologic features.

\subsection{Early Paleozoic from northern Patagonia related to the emplacement of the Terra Australis Orogen}

The oldest record for the onset of oceanic subduction along Patagonia, in the context of the Terra Australis orogen, is preserved in volcano-sedimentary successions of northern Patagonia. Metavolcanic strata dated at $\sim 535-530 \mathrm{Ma}$ from the El Jagüelito Formation are products derived from melts formed in a supra-subduction zone (González et al., 2018). The geochemistry of these rocks integrated with geological features indicates episodic pulses of extension, probably associated with slab-roll back (Greco et al., 2017; González et al., 2018). Prezzi et al. (2018) described a similar geodynamic scenario for the Cambrian Claromecó Basin, located in the southern segment of the Pampean orogen at Sierra de la Ventana (Fig. 1). According to these authors, the accommodation space necessary for the deposition of the Cambrian sequences was produced in a backarc setting during a stage of negative trench rollback. These features suggest that northern Patagonian and the southern segment of the Pampean orogen exhibit a similar early Cambrian setting (Gregori et al., 2008; Pankhurst et al., 2014; Greco et al., 2017; Prezzi et al., 2018), as early proposed by Dalla Salda et al. (1992). Temporally synchronous igneous rocks dated at 521-537 Ma in the buried basement of Tierra del Fuego (Söllner et al., 2000; Hervé et al. 2010a,b), could represent the southern representation of the Cambrian arc in Patagonia.

It should be noted that the El Jaguielito and Nahuel Niyeu formations show striking lithological, stratigraphic, biostratigraphic, and geochronological similarities as those Cambrian sequences of the Ellsworth-Whitmore, Pensacola, and Queen Maud Mountains of Antarctica (Naipauer et al., 2011; González et al. 2011a,b; 2018; Ramos and Naipauer, 2014). Hence, the Early Cambrian units of northern 
Patagonian could represent a terrane rifted-off from Antarctica and accreted to South America in pre-Devonian times (González et al., 2018).

Previous geodynamic interpretations for northern Patagonia (e.g. Ramos and Naipauer, 2014), contrast with both hypothesis above explained. A drift stage for northern Patagonia ca. 550-515, and later, the collision of the east side of Patagonia against Antarctica at ca. 515-485 during the Ross orogeny have been proposed (Ramos and Naipauer, 2014). In this regard, the collision gives place to the deposition of mollase basins, where the protoliths of the El Jagüelito Formation were deposited (Ramos and Naipauer, 2014).

The subsequent contractional phase was accompanied by regional low-to high-grade/low-pressure metamorphism of the sequence, constrained to the Furongian to Tremadocian (late Cambrian-Early Ordovician), based on U-Pb zircon dating at around of 476-462 Ma in post-orogenic granites (González et al., 2008), zircon growth at $472 \mathrm{Ma}$ in paragneisses from the Mina Gonzalito Complex (Pankhurst et al., 2006; Greco et al., 2014) and K-Ar cooling ages at ca. 451 Ma on the contact aureoles produced by these bodies on the El Jagüelito Formation (Basei et al., 2005). Despite the geological significance of this tectonic-thermal event, it still remains under discussion (González et al., 2018). The timing of orogenic events recorded by the basement units of the eastern North Patagonian Massif (Rapalini et al., 2013; Pankhurst et al., 2014; Greco et al., 2015, 2017; González et al., 2018) are synchronous and thus equivalent, indicating that all northern Patagonian units belong to a unique orogen (Greco et al., 2015, 2017; González et al., 2018).

\subsection{Middle Paleozoic record of sedimentation evidencing trench-forearc system migration in southern Patagonia}

Following closure of Cambrian basins in northern Patagonia during Early Ordovician times, the sedimentary basins from trench-forearc system were deposited in southern Patagonia exhibiting a regional deposition trend younger towards the west-southwest (Figs. 6 and 7; Hervé and Fanning, 2001; Hervé et al., 2003; Augustsson et al., 2006; Moreira et al., 2013; Permuy Vidal et al., 2014), with subsequent closing/deformation associated with variable metamorphic conditions (Ramírez-Sánchez et al., 2005; Moreira et al., 2012, 2013; Permuy Vidal et al., 2014).

The La Modesta Formation from Deseado Massif presents late Silurian-Early Devonian MDA, constrained from younger detrital zircon grains yielding ages between 446 and 413 Ma (Moreira et al., 2013), and was subsequently deformed in pre-Late Devonian times (Moreira et al., 2013), possibly associated with $\sim$ NE-SW contraction identified in the Deseado Massif (Fracchia and Giacosa, 2006). Farther west, the Cerro Negro schist exhibits Late Devonian MDA with a younger cluster of ages at $\sim 379 \mathrm{Ma}$ (Permuy Vidal et al., 2014), although the timing for deformation is still unknown. Andean outcrops of the Late Devonianearly Carboniferous EAMCn (Augustsson et al., 2006), were subsequently deformed and metamorphosed during the late CarboniferousPermian (Thomson and Hervé, 2002; Giacosa et al., 2012).

Detrital zircon patterns characterizing Silurian-Devonian basins indicate that the main provenance sources were from magmatic rocks and recycled sediments located to the east, which supports the interpretation of a forearc position with respect to the contemporaneous magmatic arc implated along the Deseado Massif. For instance, the La Modesta Formation shows a main Paleozoic relative probability peak at $\sim 473$ Ma (Fig. 7; Moreira et al., 2013), highly correlative to magmatic ages from the Deseado Massif (Loske et al., 1999; Pankhurst et al., 2003). A short-lived contractional event produced the closure of the La Modesta forearc basin, and its incorporation into the backstop. After that, the protolith deposition of the Cerro Negro schists occurred, thus showing two main provenance sources, one interpreted as the recycling of the La Modesta rocks and another correlative with the magmatic ages in the Deseado Massif (Fig. 7b).
Farther north, the protracted period of slab retreat and widening of the trench-forearc system involves the accretion of a large volume of oceanic material, interpreted as an island arc (Quezada, 2015; Hervé et al., 2016). In this regard, Hervé et al. $(2016,2018)$ produced a large geochronological dataset of $\mathrm{U}-\mathrm{Pb}$ data in zircon from sedimentary and plutonic rocks, including Hf- and O-isotopes, identifying two parallel $\sim$ N-S oriented, eastern and western Devonian magmatic belts. The eastern belt was related to east-dipping subduction of the oceanic lithosphere under Patagonia, while the western belt with more primitive compositions is represented by an oceanic island arc, called Chaitenia (Hervé et al., 2016, 2017, Hervé et al., 2018). The Chaitenia terrane was accreted possibly in Devonian times, and thus modified the trenchforearc paleogeography of Patagonia.

\subsection{Accretion of the Antarctic Peninsula terrane and oceanward migration of the subduction zone}

Diverse studies suggest that the Antarctic Peninsula was still accreted to southern Patagonia during the late Paleozoic-early Mesozoic, and was subsequently detached during the Late Jurassic opening and spreading of the Weddell Sea (Lawver et al., 1998; Jokat et al., 2003; König and Jokat, 2006; Ghidella et al., 2007; Poblete et al., 2014). However, there are unsolved questions about the timing of Antarctic Peninsula-Patagonia accretion and their joint evolution.

Both terranes share the same Permian to Triassic tectonic-magmatic evolution (Millar et al., 2002; Pankhurst et al., 2003; Hervé et al., 2010a; Calderón et al., 2010, 2016; Riley et al., 2012; Castillo et al., 2016, 2017), indicative of a Late Paleozoic connection. The in situ ages of magmatism (i.e. granitoids of intrusive character) in the Deseado Massif span from Ordovician to Early Carboniferous, while the Permian-Triassic represents the climax of subduction-related magmatism along the Antarctic Peninsula (Fig. 8; Millar et al., 2002; Riley et al., 2012). Distribution of magmatism depicts a magmatic arc stepping-out, possibly responding to the westward shifting of the subduction zone during the Antarctic Peninsula accretion. As a result of the jump outside of the subducting zone, the Permo-Triassic trench-forearc system migrates to the west and was emplaced along the Antarctic Peninsulawestern Patagonia margin (T3 in Fig. 2; Hyden and Tanner, 1981; Hervé and Fanning, 2001; Hervé et al., 2006; Castillo et al., 2015, 2016). In this way, the Permian-Triassic metamorphic complexes of western Patagonia and Antarctic Peninsula share many features as already noted by Hervé et al. (2006) and Castillo et al. (2016), supporting the connection between both terranes. Both EAMCs and the Duque de York Complex in the southernmost Chilean coast and the Trinity Peninsula Group in the Antarctic Peninsula exhibit prominent Permian detrital zircon ages peaks between 293 and $260 \mathrm{Ma}$, low-grade metamorphism, and mainly turbiditic lithology (Hervé et al., 2006; Barbeau et al., 2009; Sepúlveda et al., 2010; Castillo et al., 2016). However, in regard to the Duque de York Complex, an allochthonous origin should not be discarded (e.g. Sepúlveda et al., 2010).

Castillo et al. (2016) based on detrital zircon ages and their isotopic compositions, proposed a large forearc basin along the western flank of Antarctic Peninsula and Patagonia. Sedimentological and provenance studies in the Trinity Peninsula Group are consistent with an arc-flank basin (Hyden and Tanner, 1981; Del Valle et al., 2007; Bradshaw et al., 2012; Castillo et al., 2015), showing supply mainly from a granodioritic-tonalitic source typical from plutonic rocks formed in a subduction-related arc (Del Valle et al., 2007; Castillo et al., 2015, 2016). Towards the Late Triassic-Early Jurassic the subduction was still ongoing as evidenced by the Chonos accretionary complex, suggesting that subduction processes took place along the present Chilean coast, and therefore, the Antarctic Peninsula should have been located farther south of the Gulf of Penas. Permian and Triassic detrital zircons in the recently defined Nunatak Viedma Unit retroarc basin were interpreted as sourced from a contemporaneous magmatic arc (Suárez et al., 2019). The most likely source seems to be the Triassic Antarctic Peninsula 

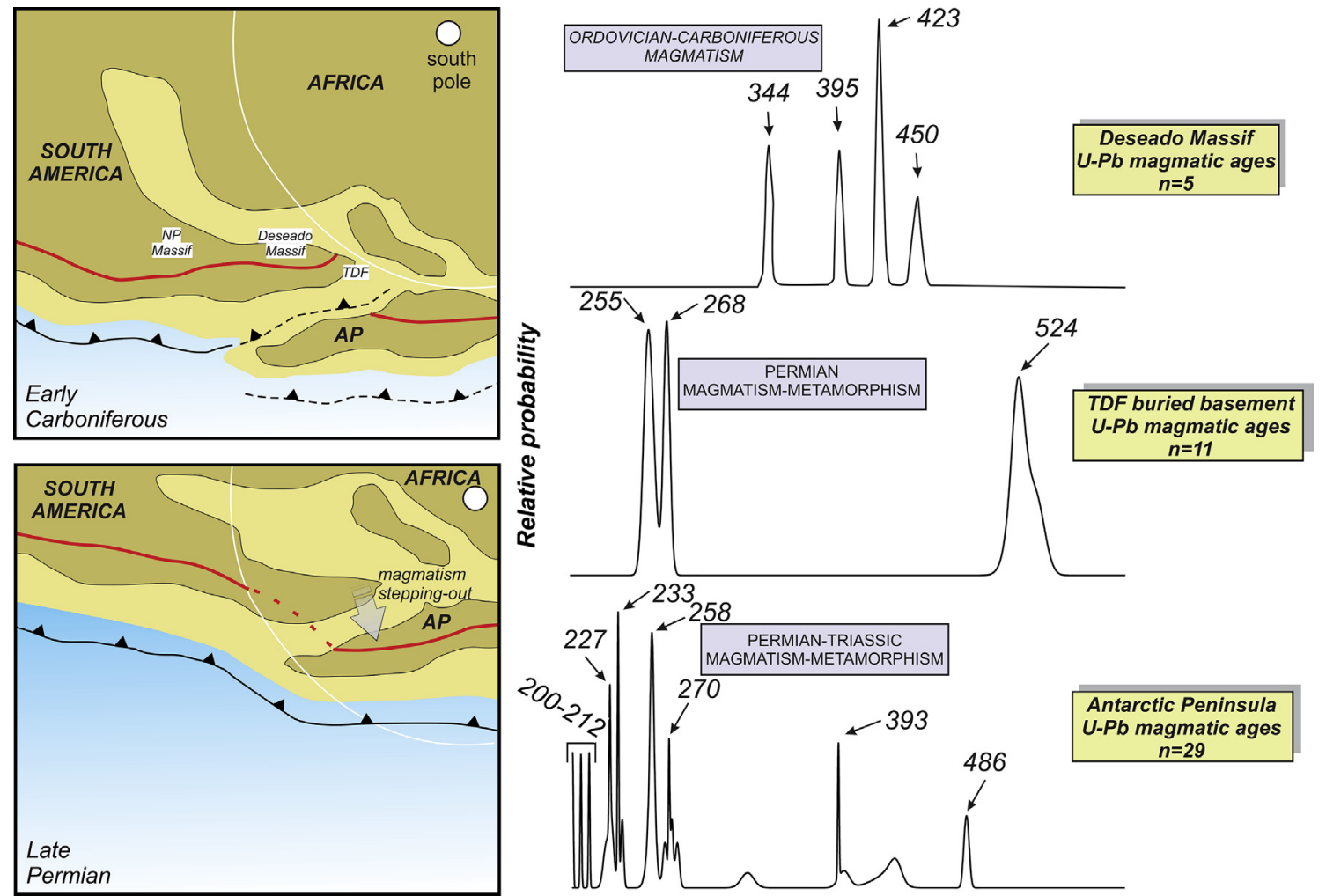

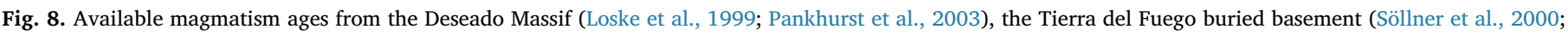

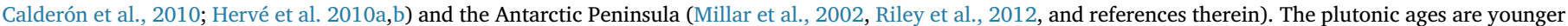

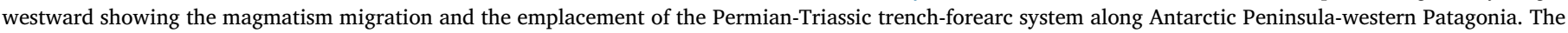

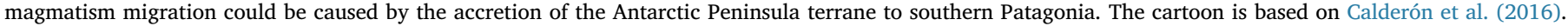

magmatic arc to explain detrital zircon age peaks (294-262 Ma, and 236-225 Ma) (Suárez et al., 2019) since those ages represent magmatic gaps in southern Patagonia. Recently, plutonic bodies yielded ages at c. 255 and c. $207 \mathrm{Ma}$ in the buried basement of Tierra del Fuego and the Deseado Massif, respectively (Castillo et al., 2017; Navarrete et al., 2019), but these ages are not widely represented in the detrital zircon age spectra of the Nunatak Viedma Unit.

\section{Concluding remarks}

In spite of multiple different theories that have been proposed to explain the origin and evolution of the Patagonian region, none seem to satisfy completely the existent data. Our contribution attempts to understand its Paleozoic-Triassic evolution in a consistent scenario with the long-lived accretionary orogenesis on the western Gondwana margin. From this review, we suggest that the Paleozoic-Triassic fossil basins from Patagonia are associated with the dynamics of the accretionary orogens characterized by the westward migration of the trenchforearc system. It is a feature common to the entire Gondwana margin during the Paleozoic-early Mesozoic (Goodge et al., 2004; Cawood, 2005; Foster et al., 2009; Cawood et al., 2011; Elliot, 2013). Thus, we differentiate three major stages of basin formation associated with the plate boundary retreating during (i) Early-to-Middle Cambrian, (ii) late Silurian-Carboniferous and (iii) Late Permian-Triassic. Each period finished with regional metamorphism and deformation events (advancing stages?) at around (i) Lower Ordovician (coeval to the Famatinian orogeny), (ii) Early-Middle Permian (Godwanide orogeny) and (iii) Late Triassic-Early Jurassic (Chonide deformation phase).

\section{Acknowledgments}

The early stage of the present work was enriched through discussions with Julio Hlebszevitsch, Mauricio Calderón, Gerson Greco and Santiago González. We wish to thank reviewers Victor Ramos, Sebastián Oriolo and Andrés Folguera for their valuable suggestions, and Maximiliano Naipauer by editorial handling. This work was carried out thanks to the financial support of grants projects Agencia PICT2013-1291 (M.C.G.), and PI-UNRN 40-A-462 and PICT-0787 ANPCyT (P.D.G).

\section{References}

Augustsson, C., Bahlburg, H., 2003a. Active or passive continental margin? Geochemical and Nd isotope constraints of metasediments in the backstop of a pre-Andean accretionary wedge in southernmost Chile $\left(46^{\circ} 30^{\prime}-48^{\circ} 30^{\prime} \mathrm{S}\right)$. In: Cann, Mc, T., Saintot, A. (Eds.), Tracing Tectonic Deformation Using the Sedimentary Record. Geological Society of London, Special Publications, pp. 253-268. https://doi.org/10.1144/GSL. SP.2003.208.01.12.

Augustsson, C., Bahlburg, H., 2003b. Cathodoluminescence spectra of detrital quartz as provenance indicators for Paleozoic metasediments in southern Andean Patagonia. J. South Am. Earth Sci. 16, 15-26. https://doi.org/10.1016/S0895-9811(03)00016-6.

Augustsson, C., Bahlburg, H., 2008. Provenance of late Palaeozoic metasediments of the Patagonian proto-Pacific margin (southernmost Chile and Argentina). Int. J. Earth Sci. 97, 71-88. https://doi.org/10.1007/s00531-006-0158-7.

Augustsson, C., Münker, C., Bahlburg, H., Fanning, M., 2006. Provenance of late Palaeozoic metasediments of the SW South American Gondwana margin: a combined $\mathrm{U}-\mathrm{Pb}$ and Hf-isotope study of single detrital zircons. J. Geol. Soc. 163, 983-995. https://doi.org/10.1144/0016-76492005-149.

Barbeau, D.L., Davis, J.T., Murray, K.E., Valencia, V., Gehrels, G.E., Zahid, K.M., Gombosi, J., 2009. Detrital-zircon geochronology of the metasedimentary rocks of northwestern Graham Land. Antarct. Sci. 22 (1), 65-78.

Basei, M.A.S., Varela, R., Passarelli, C., Siga Jr, O., Cingolani, C., Sato, A.M., González, P.D., 2005. The crystalline basement in the north of Patagonia: isotopic ages and regional characteristics. In: Pankhurst, R.J., Veiga, G. (Eds.), Geological and Biological Heritage of Gondwana. Academia Nacional de Ciencias, Córdoba, Argentina, pp. 62.

Bell, C.M., Suárez, M., 2000. The río lácteo formation of southern Chile. Late Paleozoic orogeny in the Andes of southernmost south America. J. South Am. Earth Sci. 13, $133-145$.

Boger, S.D., Miller, J., 2004. Terminal suturing of Gondwana and the onset of the RossDelamerian Orogeny: the cause and effect of an Early Cambrian reconfiguration of 
plate motions. Earth Planet. Sci. Lett. 219, 35-48.

Bradshaw, J.D., Vaughan, A.P., Millar, I.L., Flowerdew, M.J., Trouw, R.A.J., Fanning, C.M., Whitehouse, M.J., 2012. Permo-carboniferous conglomerates in the trinity Peninsula group at view point, Antarctic Peninsula: sedimentology, geochronology and isotope evidence for provenance and tectonic setting in Gondwana. Geol. Mag. 149 (2), 626-644.

Calderón, M., Hervé, F., Fuentes, F., Fosdick, J.C., Sepúlveda, F., Galaz, G., 2016. Tectonic evolution of Paleozoic and Mesozoic Andean metamorphic complexes and the Rocas Verdes Ophiolites in southern Patagonia. In: Ghiglione, M.C. (Ed.), Geodynamic Evolution of the Southernmost Andes. Springer Earth System Sciences, pp. 7-36. https://doi.org/10.1007/978-3-319-39727-6_2.

Calderón, M., Hervé, F., Massonne, H.-J., Fanning, C.M., Chavez, A., Pankhurst, R., Kraus, S., 2010. Zircon crystallization in low-pressure anatectic systems: constraints from Permian migmatites of Tierra del Fuego, southernmost South America. In: XII South American Symposium on Isotope Geology, Brasilia.

Caminos, R., 2001. Hoja Geológica 4166-I, Valcheta, provincia de Río Negro. Instituto de Geología y Recursos Minerales - Servicio Geológico Minero Argentino, Buenos Aires.

Castillo, P., Lacassie, J.P., Augustsson, C., Hervé, F., 2015. Petrography and geochemistry of the Carboniferous-triassic trinity Peninsula group, west Antarctica: implications for provenance and tectonic setting. Geol. Mag. 152 (4), 575-588.

Castillo, P., Fanning, M.C., Hervé, F., Lacassie, J.P., 2016. Characterization and tracing of Permian magmatism in the south-western segment of the Gondwanan margin; U-Pb age, Lu-Hf and O isotopic compositions of detrital zircons from metasedimentary complexes of northern Antarctic Peninsula and western Patagonia. Gondwana Res. 36, 1-13. https://doi.org/10.1016/j.gr.2015.07.014.

Castillo, P., Fanning, M.C., Pankhurst, R.J., Hervé, F., Rapela, C.W., 2017. Zircon O- and $\mathrm{Hf}$ isotope constraints on the genesis and tectonic significance of Permian magmatism in Patagonia. J. Geol. Soc. 174, 803-816. https://doi.org/10.1144/jgs2016-152.

Cawood, P.A., 2005. Terra Australis orogen: Rodinia breakup and development of the Pacific and Iapetus margins of Gondwana during the Neoproterozoic and Paleozoic. Earth Sci. Rev. 69, 249-279. https://doi.org/10.1016/j.earscirev.2004.09.001.

Cawood, P.A., Buchan, C., 2007. Linking accretionary orogenesis with supercontinent assembly. Earth Sci. Rev. 69, 249-279. https://doi.org/10.1016/j.earscirev.2004.09. 001.

Cawood, P.A., Leitch, E.C., Merle, R.E., Nemchin, A.A., 2011. Orogenesis without collision: stabilizing the Terra Australis accretionary orogen, eastern Australia. GSA Bull. 123, 11-12 2240-2255.

Cawood, P.A., McCausland, P.J.A., Dunning, G.R., 2001. Opening Iapetus: constraints from the laurentian margin in Newfoundland. GSA Bull. 113 (4), 443-453.

Chemale Jr., F., Ramos, V.A., Naipauer, M., Girelli, T.J., Vargas, M., 2018. Age of basement rocks from the Maurice Ewing bank and the Falkland/Malvinas plateau. Precambrian Res. 314, 28-40. https://doi.org/10.1016/j.precamres.2018.05.026.

Chernicoff, C.J., Zappettini, E.O., Santos, j.O.S., McNaughton, N.J., Belousova, E., 2013. Combined U-Pb SHRIMP and Hf isotope study of the late Paleozoic Yaminué complex, Rio Negro province, Argentina: implications for the origin and evolution of the Patagonia composite terrane. Geosci. Front. 4, 37-56.

Ciccioli, P.L., Limarino, C.O., Taboada, A.C., Isbell, J.L., Gulbranson, E.L., 2018. Composición modal y procedencia del Grupo Tepuel, provincia de Chubut, Argentina, vol. 3. Revista del Museo de la Plata, pp. 1 (suplemento resumenes del VII Simposio Argentino del Paleozoico Superior, Esquel, Argentina).

Cingolani, C.A., Varela, R., 1976. Investigaciones geológicas y geocronologicas en el extremo sur de la isla Gran Malvina, sector de Cabo Belgrano (Cabo Meredith), Islas Malvinas. Actas del sexto Congreso Geologico Argentino 1, 457-473.

Cucchi, R., Busteros, A., Lema, H., 2001. Hoja Geológica 4169-II Los Menúcos. Instituto de Geología y Recursos Minerales, Buenos Aires, pp. 67.

Dalla Salda, L., Cingolani, C., Varela, R., 1992. Early Paleozoic orogenic belt of the Andes in southwestern South America: Result of Laurentia-Gondwana collision? Geology 20, 617-620.

Dalziel, I.W.D., Lawver, L.A., Norton, I.O., Gahagan, L.M., 2013. The scotia arc: genesis, evolution. Glob. Significance Annu. Rev. Earth Planet. Sci. 41. https://doi.org/10. 1146/annurev-earth-050212-124155.

D'Elia, L., Muravchik, M., Franzese, J., Bilmes, A., 2012. Volcanismo de sin-rift de la Cuenca Neuquina, Argentina: relación con la evolución Triásico Tardía-Jurásico Temprano del margen Andino. Andean Geol. 39 (1), 106-132.

Del Valle, R., Heredia, N., Montes, M., Nozal, F., Martín-Serrano, A., 2007. El Grupo Trinity Peninsula en la Península Tabarín, extremo norte de la Península Antártica. Rev. Asoc. Geol. Argent. 62 (4), 498-505.

Domeier, M., 2016. A plate tectonic scenario for the Iapetus and Rheic oceans. Gondwana Res. 36, 275-295.

Du Toit, A.L., 1927. A Geological Comparison of South America with South Africa, vol. 381. Publications Carnegie Institute, pp. 1-157.

Elliot, D.H., 2013. The geological and tectonic evolution of the Transantarctic Mountains: a review. In: Hambrey, M.J., Barker, P.F., Barrett, P.J., Bowman, V., Davies, B., Smellie, J.L., Tranter, M. (Eds.), Antarctic Palaeoenvironments and Earth-Surface Processes. Geological Society, London, Special Publications, pp. 381. https://doi.org/ $10.1144 /$ SP381.14.

Falco, J.I., Hauser, N., 2017. Sedimentología y proveniencia de los depósitos de la Formación Vera (Grupo Los Menucos - triásico) en el área del Puesto Tscherig, provincia de Río Negro, Argentina. Lat. Am. J. Sedimentol. Basin Anal. 24 (2), 21-37.

Fang, Z-j., Boucot, A., Covacevich, V., Hervé, F., 1998. Discovery of late triassic fossils in the Chonos metamorphic complex, southern Chile. Rev. Geol. Chile 25 (2), 165-173.

Forsythe, R., 1982. The late Palaeozoic to early Mesozoic evolution of southern South America: a plate tectonic interpretation. J. Geol. Soc. 139, 671e682. https://doi.org/ 10.1144/gsjgs.139.6.0671.

Forsythe, R., Mpodozis, C., 1979. El Archipiélago Madre de Dios, Patagonia Occidental, Magallanes: rasgos generales de la estratigrafía y estructura del basamento pre-
Jurásico Superior. Rev. Geol. Chile 7, 13-29.

Fortey, R., Pankhurst, R.J., Hervé, F., 1992. Devonian trilobites at Buill, Chile (42 S). Rev. Geol. Chile 19 (2), 133-144.

Foster, D.A., Gray, D.R., Spaggiari, C., Kamenov, G., Bierlein, F.P., 2009. Palaeozoic Lachlan orogen, Australia; accretion and construction of continental crust in a marginal ocean setting: isotopic evidence from Cambrian metavolcanic rocks. In: In: Cawood, P.A., Kröner, A. (Eds.), Earth Accretionary Systems in Space and Time, vol. 318. The Geological Society, London, Special Publications, pp. 329-349. https://doi. org/10.1144/SP318.12.

Fracchia, D., Giacosa, R., 2006. Evolución estructural del basamento ígneo-metamórfico en la estancia Las Tres Hermanas, noreste de la comarca del Deseado, Santa Cruz. Rev. Asoc. Geol. Argent. 61 (1), 118-131.

Gallo, L.C., Tomezzoli, R.N., Cristallini, E., 2017. A pure dipole analysis of the Gondwana apparent polar wander path: paleogeographic implications in the evolution of Pangea. Geochem. Geophys. Geosyst. 18, 4. https://doi.org/10.1002/ 2016 GC006692.

Ghidella, M.E., Lawver, L.A., Marenssi, S., Gahagan, L.M., 2007. Modelos de cinemática de placas para Antártida durante la ruptura de Gondwana: una revisión. Rev. Asoc. Geol. Argent. 62 (4), 635-645.

Ghiglione, M.C., Ronda, G., Suárez, R.J., Aramendía, I., Barberón, V., Ramos, M.E., Tobal, J., Morabito, E., Martinod, J., Sue, C., 2018. Structure and tectonic evolution of the South Patagonian fold and thrust belt: Coupling between subduction dynamics, climate and tectonic deformation. In: Horton, B., Folguera, A. (Eds.), Andean Tectonics 24. Elsevier, pp. 675-697.

Giacosa, R., Fracchia, D., Heredia, N., 2012. Structure of the southern Patagonian Andes at $49^{\circ} \mathrm{S}$, Argentina. Geol. Acta 10 (3), 265-282.

Giacosa, R., Lema, H., Busteros, A., Zubia, M., Cuccchi, R., Di Tomasso, I., 2007. Estructura del Triásico de la región norte del Macizo Nordpatagónico $\left(40^{\circ}-41^{\circ} \mathrm{S}\right.$, $67^{\circ} 30^{\prime}-69^{\circ} 45^{\prime}$ O) Río Negro. Rev. Asoc. Geol. Argent. 62 (3), 355-365.

Giacosa, R., Márquez, M., 2002. El basamento paleozoico de la Cordillera Patagónica. In: In: Haller, M.J. (Ed.), Geología y Recursos Naturales de Santa Cruz. El Calafate (Buenos Aires), vol. 1. Relatorio del $15^{\circ}$ Congreso Geológico Argentino, pp. 45-55 3. Giacosa, R., Márquez, M., Nillni, A., Fernández, M., Fracchia, D., Parisi, C., Afonso, J. Paredes, J., Sciutto, J., 2004. Litología y estructura del basamento ígneo-metamórfico del borde SO del Macizo Nordpatagónico al oeste del río Chico, (Cushamen, Chubut, $\left.42^{\circ} 10^{\prime} \mathrm{S}-70^{\circ} 30^{\prime} \mathrm{O}\right)$. Rev. Asoc. Geol. Argent. 59 (4), 569-577.

Giacosa, R., Zubia, M., Sánchez, M., Allard, J., 2010. Meso-Cenozoic tectonics of the southern Patagonian foreland: Structural evolution and implications for AueAg veins in the eastern Deseado Region (Santa Cruz, Argentina). Journal of South American Earth Sciences 30, 134-150. https://doi.org/10.1016/j.jsames.2010.09.002.

González, P.D., Sato, A.M., Naipauer, M., Varela, R., Basei, M.A.S., Sato, K., Llambías, E.J., Chemale, F., Castro Dorado, A., 2018. Patagonia-Antarctica Early Paleozoic conjugate margins: Cambrian synsedimentary silicic magmatism, U-Pb dating of Kbentonites, and related volcanogenic rocks. Gondwana Res. 63, 186-225.

González, P.D., Sato, A.M., Naipauer, M., Varela, R., Llambías, E.J., Greco, G.A. González, S.N., García, V., 2011a. Conexión Macizo Norpatagónico - Antártida Oriental: fósiles arqueociátidos, comparación geológica y circones detríticos. XVIII Congreso Geológico Argentino. Neuquén S1.

González, P.D., Sato, A.M., Varela, R., Llambías, E.J., Naipauer, M., Basei, M.A.S., Campos, H., Greco, G.A., 2008. El Molino Pluton: a granite with regional metamorphism within el Jagüelito Formation, north Patagonian massif. In: XI South American Symposium on Isotope Geology. San Carlos de Bariloche.

González, P.D., Tortello, M.F., Damborenea, S.E., 2011b. Early Cambrian Archaeocyathan limestone blocks in low-grade meta-conglomerate from el Jagüelito Formation (Sierra Grande, río Negro, Argentina). Geol. Acta 9, 159-173. https://doi.org/10. 1344/105.000001650.

González, S.N., Greco, G.A., González, P.D., Sato, A.M., Llambías, E.J., Varela, R., 2016. Geochemistry of a triassic dyke swarm in the north Patagonian massif, Argentina. Implications for a postorogenic event of the Permian Gondwanide orogeny. J. South Am. Earth Sci. 70, 69-82. https://doi.org/10.1016/j.jsames.2016.04.009.

González, S.N., Greco, G.A., Sato, A.M., Llambías, E.J., Basei, M.A.S., González, P.D., Díaz, P.E., 2017. Middle Triassic trachytic lava flows associated with coeval dyke swarm in the North Patagonian Massif: a postorogenic magmatism related to extensional collapse of the Gondwanide orogen. J. South Am. Earth Sci. 75, 134-143. https://doi.org/10.1016/j.jsames.2017.02.007.

González Bonorino, G., 1991. Late Paleozoic orogeny in the northwestern Gondwana continental margin, western Argentina and Chile. J. South Am. Earth Sci. 42 (1-2), $131-144$.

González Bonorino, G., 1992. Carboniferous glaciations in Gondwana. Evidence for grounded marine ice and continental glaciation in southwestern Argentina. Palaeogeogr. Palaeoclimatol. Palaeoecol. 91, 363-375.

Goodge, J., Williams, I., Myrow, P., 2004. Provenance of Neoproterozoic and lower Paleozoic siliciclastic rocks of the central Ross orógeno, Antarctica: detrital record of rift-, passive- and active-margin sedimentation. Geol. Soc. Am. Bull. 116 (9-10), 1253-1279.

Greco, G.A., González, S.N., González, P.D., Llambías, E.J., Basei, M.A.S., 2014. Nueva datación en circones detríticos para el Complejo Mina Gonzalito, Provincia de Río Negro. In: Martino, R.D. (Ed.), Asociación Geológica Argentina, Córdoba, pp. $1454-1455$.

Greco, G.A., González, P.D., González, S.N., Sato, A.M., Basei, M.A.S., Tassinari, C.C.G., Sato, K., Varela, R., Llambías, E., 2015. Geology, structure and age of the Nahuel Niyeu formation in the Aguada Cecilio area, north Patagonian massif, Argentina. J. South Am. Earth Sci. 62, 12-32.

Greco, G.A., González, S.N., Sato, A.M., González, P.D., Basei, M.A.S., Llambías, E.J., Varela, R., 2017. The Nahuel Niyeu basin: a Cambrian forearc basin in the eastern North Patagonian massif. J. South Am. Earth Sci. 79, 111-136. https://doi.org/10. 
1016/j.jsames.2017.07.009.

Gregori, D., Kostadinoff, L., Strazzere, A., 2008. Tectonic significance and consequences of the Gondwanide orogeny in northern Patagonia, Argentina. Gondwana Res. 14, 429-450.

Griffis, N.P., Montañez, I.P., Fedorchuk, N., Isbell, J., Mundil, R., Vesely, F., Weinshultz, L., Iannuzzi, R., Gulbranson, E., Taboada, A., Pagani, A., Sanborn, M.E., Huyskens, M., Wimpenny, J., Linol, B., Yin, Q.-Z., 2018. Isotopes to ice: constraining provenance of glacial deposits and ice centers in west-central Gondwana. Palaeogeogr. Palaeoclimatol. Palaeoecol. https://doi.org/10.1016/j.palaeo.2018.04.020.

Grunow, A.M., 1993. New paleomagnetic data from the Antarctica Peninsula and their tectonic implications. J. Geophys. Res. Solid Earth 98, 13815-13833.

Heredia, N., García-Sansegundo, J., Gallastegui, G., Farias, P., Giacosa, R.E., Hongn, F.D., Tubía, J.M., Alonso, J.L., Busquets, P., Charrier, R., Clariana, P., Colombo, F., Cuesta, A., Gallastegui, J., Giambiagi, L.B., González-Menéndez, L., Limarino, C.O., MartínGonzález, F., Pedreira, D., Quintana, L., Rodríguez-Fernández, L.R., Rubio-Ordóñez, A., Seggiaro, R.E., Serra-Varela, S., Spalletti, L.A., Cardó, R., Ramos, V.A., 2018. The Pre-Andean phases of construction of the Southern Andes basement in Neoproterozoic-Paleozoic times. In: The Evolution of the Chilean-Argentinean Andes. Springer, Cham, pp. 111-131.

Hervé, F., Aguirre, L., Sepúlveda, V., Morata, D., 1999. Contrasting geochemistry and metamorphism of pillow basalts in metamorphic complexes from Aysén, S. Chile. J. South Am. Earth Sci. 12, 379-388.

Hervé, F., Mpodozis, C., Davidson, J.A., Godoy, E.P., 1981. Observaciones estructurales y petrográficas en el basamento metamórfico del archipielago de los Chonos, entre el canal King y el canal Ninualac, Aisen. Rev. Geol. Chile 13-14, 3-16.

Hervé, F., Calderón, M., Fanninc, M.C., Pankhurst, R.J., Rapela, C.W., Quezada, P., 2018. The country rocks of Devonian magmatism in the North Patagonian Massif and Chaitenia. Andean Geol. 45 (3), 301-317. https://doi.org/10.5027/andgeoV45n33117.

Hervé, F., Calderón, M., Fanning, M., Kraus, S., Pankhurst, R.J., 2010a. SHRIMP chron ology of the Magallanes Basin basement, Tierra del Fuego: Cambrian plutonism and Permian high-grade metamorphism. Andean Geol. 37 (2), 253-275.

Hervé, F., Calderón, M., Fanning, M., Pankhurst, R., Fuentes, F., Correa, J., Quezada, P., Rapela, C.W., 2017. Devonian accretion south of Chilenia. In: XX Congreso Geológico Argentino. San Miguel de Tucumán, pp. S13.

Hervé, F., Calderón, M., Fanning, M., Pankhurst, R., Fuentes, F., Rapela, C.W., Correa, J., Quezada, P., Marambio, C., 2016. Devonian magmatism in the accretionary complex of southern Chile. J. Geol. Soc. 173, 587-602. https://doi.org/10.1144/jgs2015-163.

Hervé, F., Calderón, M., Faúndez, V., 2008. The metamorphic complexes of the Patagonian and Fuegian Andes. Geol. Acta 6 (1), 43-53. https://doi.org/10.1344/ 105.000000240.

Hervé, F., Fanning, C.M., 2001. Late triassic zircons in metaturbidites of the Chonos metamorphic complex, southern Chile. Rev. Geol. Chile 28 (1), 91-104.

Hervé, F., Fanning, C.M., Pankhurst, R.J., 2003. Detrital zircon age patterns and provenance of the metamorphic complexes of southern Chile. J. South Am. Earth Sci. 16, 107-123. https://doi.org/10.1016/S0895-9811(03)00022-1.

Hervé, F., Fanning, C.M., Pankhurst, R.J., Mpodozis, C., Klepeis, K., Calderón, M., Thomson, S.N., 2010b. Detrital zircon SHRIMP U-Pb age study of the Cordillera Darwin Metamorphic Complex of Tierra del Fuego: sedimentary sources and implications for the evolution of the Pacific margin of Gondwana. J. Geol. Soc. 167, 555-568. https://doi.org/10.1144/0016-76492009-124.

Hervé, F., Haller, M., Duhart, P., Fanning, C.M., 2005. SHRIMP U-Pb ages of detrital zircons from Cushamen and Esquel formations, North Patagonian Massif Argentina: geological implications. In: XVI Congreso Geológico Argentino. La Plata, Actas, pp. 309-314.

Hervé, F., Miller, H., Pimpirev, C., 2006. Patagonia-Antarctica connections before Gondwana break-up. In: Fütterer, D.K., Dmaske, D., Kleinschmidt, G., Miller, H., Tessensohn, F. (Eds.), Antarctica: Contributions to Global Earth Sciences. SpringerVerlag, pp. 217-227.

Hlebszevitsch, J.C., Cortiñas, J.S., 2009. El registro más antiguo de Echinoidea en Argentina y el contacto Pérmico - Jurásico Inferior en la región del Río Geona, Chubut. Rev. Asoc. Geol. Argent. 65 (3), 479-486.

Hunter, M.A., Lomas, S.A., 2003. Reconstructing the siluro-Devonian coastline of Gondwana: insights from the sedimentology of the Porth Stephens formation, Falkland Islands. J. Geol. Soc. 160, 459-476.

Hyden, G., Tanner, P.W.G., 1981. Late Paleozoic-Early Mesozoic fore-arc basin sedimentary rocks at the Pacific margin in Western Antarctica. Geol. Rundsch. 70, 529-541.

Jacobs, J., Thomas, R.J., Armstrong, A., Henjes-Kunst, F., 1999. Age and thermal evolution of the Mesoproterozoic Cape Meredith complex, west Falkland. J. Geol. Soc. 156, 917-928.

Jenchen, U., 2018. Petrography and geochemistry of the triassic el Tranquilo group Deseado massif, Patagonia, Argentina: implications for provenance and tectonic setting. J. South Am. Earth Sci. 88, 530-550.

Jokat, W., Boebel, T., König, M.Y., Meyer, U., 2003. Timing and geometry of early Gondwana breakup. J. Geophys. Res. 108 (B9), 2428. https://doi.org/10.1029/ 2002JB001802.

König, M., Jokat, W., 2006. The Mesozoic breakup of the Weddell sea. J. Geophys. Res Solid Earth 111 (B12), 1-28.

Keidel, J., 1916. La geologfa de las sierras de la Provfncia de Buenos Aires y sus relaciones con las montañas de Sud Africa y los Andes. Anales Ministerio Agricultura Nación, Sección Geologfa, Mineralogía Minería, Buenos Aires IX (3), 1-78.

Kraemer, P., Riccardi, A., 1997. Estratigrafía de la región comprendida entre los lagos Argentino y Viedma, Santa Cruz. Revista Asociación Geológica Argentina 52 (3), 333-360.

Lacassie, J.P., 2003. Estudio de la Proveniencia Sedimentaria de los Complejos
Metamórficos de los Andes Patagónicos (46- 51 Lat. S), mediante la aplicación de redes neuronales e isótopos estables. PhD thesis. Universidad de Chile 173pp.

Lawver, L.A., Gahagan, L.M., Dalziel, W.D., 1998. A tight fit-early Mesozoic Gondwana, a plate reconstruction perspective. Mem. Natl. Inst. Polar Res. 53, 214-228.

Limarino, C.O., Spalletti, L.A., 2006. Paleogeography of the upper Paleozoic basins of southern South America: an overview. J. South Am. Earth Sci. 22, 134-155.

Llambías, E., Rapela, C.W., 1984. Geología de los complejos eruptivos de La Esperanza, provincia de Río Negro. Rev. Asoc. Geol. Argent. 34 (3-4), 220-243.

Loske, W., Márquez, M., Giacosa, R., Pezzuchi, H., Fernández, M.I., 1999. U/Pb geochronology of pre-Permian basement rocks in the Macizo del Deseado, Santa Cruz province, Argentine Patagonia. In: XIV Congreso Geológico Argentino. Actas 1. Asociación Geológica Argentina, pp. 102-103.

Luppo, T., López de Luchi, M., Rapalini, A.E., Martínez Dopico, C.I., Fanning, C.M., 2018 Geochronologic evidence of a large magmatic province in northern Patagonia encompassing the Permian-Triassic boundary. J. South Am. Earth Sci. 82, 346-355.

Luppo, T., Martínez Dopico, C.I., Rapalini, A.E., López de Luchi, M., Miguez, M., Fanning, C.M., 2019. Paleomagnetism of Permo-Triassic volcanic units in northern Patagonia: are we tracking the final stages of collision of Patagonia? Int. J. Earth Sci. 108, 621-647.

Manceñido, M.O., Damborenea, S.E., 1984. Megafauna de Invertebrados Paleozoicos y Mesozoicos. In: In: Ramos, V. (Ed.), Geología y Recursos Naturales de la Provincia de Río Negro. $9^{\circ}$ Congreso Geológico Argentino, Relatorio, vol. 2 (5), 413-465. San Carlos de Bariloche.

Marcos, P., Gregori, D.A., Benedini, L., Barros, M., Strazzere, L., Pavón Pivetta, C., 2018. Pennsylvanian glacimarine sedimentation in the Cushamen Formation, western North Patagonian massif. Geosci. Front. 9, 485-504.

Márquez, M., Navarrete, C., 2011. Cabo Blanco: an Unknown Silurian- Devonian? Fragment of West Gondwana in Southern Patagonia, Argentina, vol. 14. Abstracts Gondwana, Rio de Janeiro, pp. 156.

Martínez, M., 2002. Tectonic, Magmatic and Metamorphic Evolution of the Prepermian Basement of the Northeastern Deseado Massif, Patagonia, Argentina. Dissertation. pp. 233 (Bochum).

Millar, I.L., Pankhurst, R.J., Fanning, C.M., 2002. Basement chronology of the Antarctic Peninsula: recurrent magmatism and anatexis in the Palaeozoic Gondwana margin. J. Geol. Soc. 159, 145-157. https://doi.org/10.1144/0016-764901-020.

Moreira, P., González, P.D., Fernández, R., Echeveste, H., Schalamuk, I.A., Etcheverry, R., 2005. El basamento metamórfico de muy bajo a bajo grado de las estancias La Modesta y La Josefina, macizo del Deseado, provincia de Santa Cruz. Rev. Asoc. Geol. Argent. 60 (1), 49-63.

Moreira, P., González, P.D., Fernández, R., Echeveste, H., Schalamuk, I.A., 2012. Estructura y metamorfismo de la Formación La Modesta en la estancia El Tranquilo (Santa Cruz), Patagonia. Rev. Asoc. Geol. Argent. 69 (1), 19-27.

Moreira, P., Fernández, R., Hervé, F., Fanning, C.M., Schalamuk, I.A., 2013. Detrital zircons U-Pb SHRIMP ages and provenance of La Modesta Formation, Patagonia Argentina. J. South Am. Earth Sci. 47, 32-46. https://doi.org/10.1016/j.jsames. 2013.05.010.

Müller, H., 1965. Zur Alterfrage der eisenerzlagerstätte Sierra Grande/Río Negro in Nordpatagonien Aufgrund neuer Fossilfunde. Geol. Rundsch. 54, 715-732.

Müller, D., Cannon, J., Qin, X., Watson, R.J., Gurnis, M., Williams, S., Pfaffelmoser, T., Seton, M., Russell, S.H.J., Zahirovic, S., 2018. GPlates: Building a virtual earth through deep time. Geochem. Geophys. Geosyst. 19, 2243-2261. https://doi.org/10. 1029/2018GC007584.

Naipauer, M., González, P.D., Varela, R., Sato, A.M., Chemale Jr., , Llambías, E., Greco, G., 2011. Edades U-Pb (LA-ICP-MS) en circones detríticos del Miembro Polke, Formación Sierra Grande, Río Negro: ¿una nueva unidad cambro-ordovícica? In: XVIII Congreso Geológico Argentino S1 Neuquén.

Navarrete, C., Gianni, G., Encinas, E., Márquez, M., Kamerbeek, Y., Valle, M., Folguera, A., 2019. Triassic to middle jurassic geodynamic evolution of southwestern Gondwana: from a large flat-slab to mantle plume suction in a rollback subduction setting. Earth Sci. Rev. 194, 125-159.

Oriolo, S., Oyhantçabal, P., Wemmer, K., Siegesmund, S., 2017. Contemporaneous assembly of Western Gondwana and final Rodinia break-up: Implications for the supercontinent cycle. Geosci. Front. 8, 1431-1445. https://doi.org/10.1016/j.gsf.2017. 01.009 .

Oriolo, S., Schulz, B., González, P.D., Bechis, F., Olaizola, E., Krause, J., Renda, E., Vizán, H, 2019. The Late Paleozoic tectonometamorphic evolution of Patagonia revisited: Insights from the pressure-temperature-deformation-time (P-T-D-t) path of the Gondwanide basement of the North Patagonian Cordillera (Argentina). Tectonics. https://doi.org/10.1029/2018TC005358.

Pankhurst, R.J., Rapela, C.W., Fanning, C.M., Márquez, M., 2006. Gondwanide continental collision and the origin of Patagonia. Earth Sci. Rev. 76 (3-4), 235-257.

Pankhurst, R.J., Rapela, C.W., López de Luchi, M.G., Rapalini, A.E., Fanning, C.M., Galindo, C., 2014. The Gondwana connections of northern Patagonia. J. Geol. Soc. 171, 313-328.

Pankhurst, R.J., Rapela, C.W., Loske, W.P., Márquez, M., Fanning, C.M., 2003. Chronological study of the pre-Permian basement rocks of southern Patagonia. J. South Am. Earth Sci. 16 (1), 27-44.

Permuy Vidal, C., Moreira, P., Guido, D.M., Fanning, C.M., 2014. Linkages between the southern Patagonia Pre-Permian basements: new insights from detrital zircons U-Pb SHRIMP ages from the Cerro Negro District. Geol. Acta 12 (2), 137-150.

Pisarevsky, S.A., Wingate, M.T.D., Powell, C.M., Johnson, S., Evans, D.A., 2003. Models of Rodinia assembly and fragmentation. Geol. Soc. Lond. Specl. Publ. 206, 35-55. https://doi.org/10.1144/GSL.SP. 2003.206.01.04.

Platt, N.H., Philip, P.R., 1995. Structure of the southern Falkland Islands continental shelf: initial results from new seismic data. Mar. Pet. Geol. 12 (7), 759-771.

Poblete, F., Arriagada, C., Roperch, P., Astudillo, N., Hervé, F., Kraus, S., Le Roux, J.P., 
2011. Paleomagnetism and tectonics of the south shetland islands and the northern Antarctic Peninsula. Earth Planet. Sci. Lett. 302, 299-313.

Poblete, F., Roperch, P., Arriagada, C., Ruffet, G., Ramírez de Arellano, C., Hervé, F., Poujol, M., 2016. Late Cretaceous-early Eocene counterclockwise rotation of the Fueguian Andes and evolution of the Patagonia-Antarctic Peninsula system. Tectonophysics 668-669 (8), 15-34.

Poblete, F., Roperch, P., Hervé, F., Diraison, M., Espinoza, M., Arriagada, C., 2014. The curved Magallanes fold and thrust belt: Tectonic insights from a paleomagnetic and anisotropy of magnetic susceptibility study. Tectonics 33, 2526-2551. https://doi. org/10.1002/2014TC003555.

Poiré, D.G., Morel, E., Cannesa, N.D., Calvo Marcilese, L., Povilauskas, L., 2003. La Formación Bahía de La Lancha, Paleozoico de los Andes Patagónicos Australes: Hipótesis de trabajo sobre sus paleoambientes y edad. III Simposio Argentino del Paleozoico Superior, La Plata.

Poiré, D.G., Morel, E., Maggi, J.H., 1999. Facies diamictíticas en la Formación Bahía de la Lancha (Paleozoico), Estancia La Lila, Lago San Martín, provincia de Santa Cruz, Argentina. In: $14^{\circ}$ Congreso Geológico Argentino, Actas, vol. 1. pp. 425-428 (Salta).

Prezzi, C.B., Vizán, H., Vázquez, S., Renda, E., Oriolo, S., Japas, M.S., 2018. Evolution of the Paleozoic Claromecó Basin (Argentina) and geodynamic implications for the southwestern margin of Gondwana: insights from isostatic, gravimetric and magnetometric models. Tectonophysics 742-743, 120-136.

Quezada, P.A., 2015. Geología del basamento de la Región de los Lagos, Chile; evidencias de magmatismo calco-alcalino y aportes sedimentarios devónicos. Memoria para optar al título de Geólogo, Universidad de Chile, Santiago de Chile.

Ramírez-Sánchez, E., Hervé, F., Kelm, U., Sassi, R., 2005. P-T conditions of metapelites from metamorphic complexes in Aysen, Chile. J. South Am. Earth Sci. 19, 373-386.

Ramos, V.A., 1984. Patagonia: ¿un continente Paleozoico a la deriva? $9^{\circ}$ Congreso Geológico Argentino 2, 311-325 San Carlos de Bariloche.

Ramos, V.A., 2004. La Plataforma Patagónica y sus relaciones con la Plataforma Brasilera. Geologia do Continente Sul-Americano. Sociedade Brasileira de Geologia, pp. 371-381.

Ramos, V.A., 2008. Patagonia: a Paleozoic continent adrift? J. South Am. Earth Sci. 26, 235-251. https://doi.org/10.1016/j.jsames.2008.06.002.

Ramos, V.A., 2010. The Grenville-age basement of the Andes. J. South Am. Earth Sci. 29, 77-91. https://doi.org/10.1016/j.jsames.2009.09.004.

Ramos, V.A., Cingolani, C., Chemale Jr., F., Naipauer, M., Rapalini, A., 2017. The Malvinas (Falkland) Islands revisited: the tectonic evolution of southern Gondwana based on U-Pb and Lu-Hf detrital zircon isotopes in the Paleozoic cover. J. South Am. Earth Sci. 76, 320-345. https://doi.org/10.1016/j.jsames.2016.12.013.

Ramos, V.A., Naipauer, M., 2014. Patagonia: where does it come from? J. Iber. Geol. 40 (2), 367-379.

Rapalini, A.E., Tarling, D.H., Turner, P., Flint, S., Vilas, J.F., 1994. Paleomagnetism of the Carboniferous Tepuel group, central Patagonia, Argentina. Tectonics 13 (5), 1277-1294.

Rapalini, A.E., 1998. Syntectonic magnetization of the mid-Palaeozoic Sierra Grande Formation: further constraints on the tectonic evolution of Patagonia. J. Geol. Soc. $155,105-114$.

Rapalini, A., López de Luchi, M., Martínez Dopico, C., Lince Klinger, F., Giménez, M., Martínez, P., 2010. Did Patagonia collide with Gondwana in the late Paleozoic? Some insights from a multidisciplinary study of magmatic units of the north Patagonian massif. Geol. Acta 8 (4), 349-371.

Rapalini, A.E., López de Luchi, M., Tohver, E., Cawood, P.A., 2013. The South American ancestry of the North Patagonian Massif: geochronological evidence for an autochthonous origin? Terra. Nova 25, 337-342. https://doi.org/10.1111/ter.12043.

Rapela, C.W., Caminos, R., 1987. Geochemical characteristics of the upper Paleozoic magmatism in the eastern sector of North Patagonian Massif. Rev. Bras. Geociencias 17 (4), 535-543.

Rapela, C.W., Llambías, E., 1985. Evolución magmática y relaciones regionales de los complejos eruptivos de La Esperanza, provincia de Río Negro. Rev. Asoc. Geol. Argent. 40 (1-2), 4-25.

Riccardi, A., 1971. Estratigrafía en el oriente de la Bahía de la Lancha, Lago San Martín, Santa Cruz, Argentina. Revista Museo de la Plata 61 (7), 245-318.

Riley, T.R., Flowerdew, M.J., Whitehouse, M.J., 2012. U-Pb ion-microprobe zircon geochronology from the basement inliers of eastern Graham Land, Antarctic Peninsula. J. Geol. Soc. 169 (4), 381-393.

Rustan, J., Cingolani, C., Cicardi, A., Uriz, N., 2013. Lower silurian trilobites from the northern Patagonia Sierra Grande Formation. Ameghiniana 50, 6 Suplemento 2013, Resumen R 68.

Schilling, M.E., Carlson, R.W., Tassara, A., Conceição, R.V., Bertotto, G.W., Vázquez, M., Muñoz, D., Jalowitzki, T., Gervasoni, F., Morata, D., 2017a. The origin of Patagonia revealed by Re-Os systematics of mantle xenoliths. Precambrian Res. 294, 15-32. https://doi.org/10.1016/j.precamres.2017.03.008.
Schmitt, R.S., Fragoso, R.A., Collins, A.S., 2018. Suturing Gondwana in the Cambrian: the orogenic events of the final amalgamation. In: Siegesmund, S., Basei, M.,

Oyhantçabal, P., Oriolo, S. (Eds.), Geology of Southwest Gondwana. Regional Geology Reviews. Springer, Cham, pp. 411-432.

Sepúlveda, F.A., Palma-Heldt, S., Hervé, F., Fanning, M.C., 2010. Permian depositional age of metaturbidites of the Duque de York Complex, southern Chile: U-Pb SHRIMP data and palynology. Andean Geol. 37 (2), 375-397.

Serra-Varela, S., González, P., Giacosa, R., Heredia, N., Pedreira, D., Martín-González, F., Sato, A.M., 2019. Evolution of the Palaeozoic basement of the Northpatagonian Andes in the San Martín de los Andes area (Neuquén, Argentina): Petrology, age and correlations. Andean Geol. 46 (1), 102-130. https://doi.org/10.5027/andgeoV46n13124.

Seton, M., Müller, R.D., Zahirovic, S., Gaina, C., Torsvik, T., Shephard, G., Talsma, A. Gurnis, M., Turner, M., Maus, S., Chandler, M., 2012. Global continental and ocean basin reconstructions since 200 Ma. Earth Sci. Rev. 113, 212-270. https://doi.org/ 10.1016/j.earscirev.2012.03.002.

Siccardi, A., Uriz, N., Rustán, J., Cingolani, C., 2014. Hirnantian?-Early silurian brachiopods from the Sierra Grande Formation (north Patagonian massif, río Negro province, Argentina). In: 4th International Palaeontological Congress, Abstract Volume 807p. Mendoza.

Söllner, F., Miller, H., Hervé, M., 2000. An Early Cambrian granodiorite age from the preAndean basement of Tierra del Fuego (Chile): the missing link between South America and Antarctica? J. South Am. Earth Sci. 13, 163-177.

Spalletti, L.A., 1993. An iron-bearing wave-dominated siliciclastic shelf: facies analysis and palaeogeographic implications (Silurian-Lower Devonian Sierra Grande Formation, Southern Argentina). Geol. J. 28, 137-148.

Suárez, R.J., Ghiglione, M.C., Calderón, M., Sue, C., Martinod, J., Guillaume, B., Rojo, D. 2019. The metamorphic rocks of the Nunatak Viedma in the southern Patagonian Andes: provenance sources and implications for the early Mesozoic PatagoniaAntarctic Peninsula connection. J. South Am. Earth Sci. 90, 471-486.

Thomson, S.N., Hervé, F., 2002. New time constraints for the age of metamorphism at the ancestral Pacific Gondwana margin of souther Chile (42-52 ${ }^{\circ}$ S). Rev. Geol. Chile 28 (2), 255-271.

Tomezzoli, R.N., 2012. Chilenia y Patagonia: ¿un mismo continente a la deriva? Rev. Asoc. Geol. Argent. 69 (2), 222-239.

Trouw, R.A.J., De Wit, M., 1999. Relation between the Gondwanide Orogen and contemporaneous intracratonic deformation. J. Afr. Earth Sci. 28 (1), 203-213.

Uriz, N.J., Cingolani, C.A., Chemale Jr., F., Macambira, B., Armstrong, R., 2011. Isotopic studies on detrital zircons of Silurian-Devonian siliciclastic sequences from Argentinean North Patagonia and Sierra de la Ventana regions: comparative provenance. Int. J. Earth Sci. 100, 571-589.

van Staal, C.R., Dewey, J.F., Mac Niocaill, C., McKerrow, W.S., 1998. The CambrianSilurian tectonic evolution of the Northern Appalachians and British Caledonides; history of a complex, west and southwest Pacific-type segment of Iapetus. In: In: Blundell, D., Scott, A.C. (Eds.), Lyell: the Past Is the Key to the Present, vol. 143. Geological Society of London, Special Publication, pp. 199-242.

Varela, R., Basei, M.A.S., Cingolani, C.A., Siga Jr., O., Passarelli, C.R., 2005. El basamento cristalino de los Andes norpatagónicos en Argentina: geocronología e interpretación tectónica. Rev. Geol. Chile 32 (2), 167-187.

Varela, R., Sato, K., González, P., Sato, A., Basei, M., 2009. Geología y geocronología RbSr de granitoides de Sierra Grande, Provincia de Río Negro. Rev. Asoc. Geol. Argent. 64 (2), 274-283.

Vaughan, A.P.M., Storey, B.C., 2000. The eastern Palmer Land shear zone: a new terrane accretion model for the Mesozoic development of the Antarctic Peninsula. J. Geol. Soc. 157, 1243-1256. http://doi.org/10.1144/jgs.157.6.1243.

Vaughan, A.P.M., Eagles, G., Flowerdew, M.J., 2012. Evidence for a two-phase Palmer Land event from crosscutting structural relationships and emplacement timing of the lassiter coast intrusive suite, Antarctic Peninsula: implications for mid-Cretaceous southern ocean plate configuration. Tectonics 31, TC1010.

von Gosen, W., 2003. Thrust tectonics in the north Patagonian massif (Argentina): implications for a Patagonia plate. Tectonics 22 (1), 1005. https://doi.org/10.1029/ 2001TC901039.

von Gosen, W., Loske, W., 2004. Tectonic history of the Calcatapul Formation, Chubut province, Argentina, and the "Gastre fault system". J. South Am. Earth Sci. 18, 73-88. https://doi:10.1016/j.jsames.2004.08.007.

Wareham, C.D., Pankhurst, R.J., Thomas, R.J., Storey, B.C., Grantham, G.H., Jacobs, J., Eglington, B.M., 1998. Pb, Nd, and Sr isotope mapping of Grenville-age crustal Provinces in Rodinia. J. Geol. 106, 647-659. https://doi.org/10.1086/516051.

Willner, A., Hervé, F., Massonne, H.J., 2000. Mineral chemistry and pressure-temperature evolution of two contrasting high-pressure-low-temperature belts in the Chonos Archipelago, Southern Chile. J. Petrol. 41 (3), 309-330. https://doi.org/10.1093/ petrology/41.3.309. 